\title{
A Novel Conditional Genetic System Reveals That Increasing Neuronal cAMP Enhances Memory and Retrieval
}

\author{
Carolina Isiegas, ${ }^{1}$ Conor McDonough, ${ }^{1}$ Ted Huang, ${ }^{1}$ Robbert Havekes, ${ }^{1}$ Sara Fabian, ${ }^{1}$ Long-Jun Wu, ${ }^{2}$ Hui Xu, ${ }^{2}$ \\ Ming-Gao Zhao, ${ }^{2}$ Jae-Ick Kim, ${ }^{3}$ Yong-Seok Lee, ${ }^{3}$ Hye-Ryeon Lee, ${ }^{3}$ Hyoung-Gon Ko, ${ }^{3}$ Nuribalhae Lee, ${ }^{3}$ Sun-Lim Choi, ${ }^{3}$ \\ Jeong-Sik Lee, ${ }^{4,5}$ Hyeon Son, ${ }^{4,5}$ Min Zhuo, ${ }^{2}$ Bong-Kiun Kaang, ${ }^{3}$ and Ted Abel ${ }^{1}$ \\ ${ }^{1}$ Department of Biology, University of Pennsylvania, Philadelphia, Pennsylvania 19104, ${ }^{2}$ Department of Physiology, Faculty of Medicine, University of \\ Toronto, Toronto, Ontario, Canada M5S 1A8, ${ }^{3}$ National Creative Research Initiative Center for Memory, Department of Biological Sciences, College of \\ Natural Sciences, Seoul National University, Seoul 151-747, South Korea and Departments of ${ }^{4}$ Biochemistry and ${ }^{5}$ Molecular Biology, Hanyang University \\ College of Medicine, Seoul 133-791, South Korea
}

Consistent evidence from pharmacological and genetic studies shows that cAMP is a critical modulator of synaptic plasticity and memory formation. However, the potential of the cAMP signaling pathway as a target for memory enhancement remains unclear because of contradictory findings from pharmacological and genetic approaches. To address these issues, we have developed a novel conditional genetic system in mice based on the heterologous expression of an Aplysia octopamine receptor, a G-protein-coupled receptor whose activation by its natural ligand octopamine leads to rapid and transient increases in cAMP. We find that activation of this receptor transgenically expressed in mouse forebrain neurons induces a rapid elevation of hippocampal cAMP levels, facilitates hippocampus synaptic plasticity, and enhances the consolidation and retrieval of fear memory. Our findings clearly demonstrate that acute increases in cAMP levels selectively in neurons facilitate synaptic plasticity and memory, and illustrate the potential of this heterologous system to study cAMP-mediated processes in mammalian systems.

Key words: cAMP; conditional genetic system; octopamine; synaptic plasticity; memory; retrieval

\section{Introduction}

In the brain, activation of cAMP signaling occurs after stimulation of adenylyl cyclases by stimulatory G-proteins after binding of an extracellular ligand to a G-protein-coupled receptor (GPCR) and by $\mathrm{Ca}^{2+}$ through the $\mathrm{Ca}^{2+}$-binding protein calmodulin (Wang and Storm, 2003). Genetic and pharmacological studies provide strong evidence that the cAMP signaling pathway is crucial for learning and memory across species [for reviews, see Kandel (2004) and Skoulakis and Grammenoudi (2006)]. However, critical questions remain about the potential of this pathway as a target for memory enhancement because of contradictory results from pharmacological and genetic studies. Elevation of cAMP levels by rolipram, an inhibitor of phosphodiesterases responsible for cAMP breakdown, or by forskolin, an activator of

Received June 28, 2007; revised April 9, 2008; accepted April 29, 2008.

This work was supported by grants from the National Institutes of Health (T.A.), the Human Frontiers Science Program (T.A.), Predoctoral Training Program Fellowship in Neuropsychopharmacology T32MH014654 (C.M.; Dr. Irwin Lucki was the primary investigator), Ruth L. Kirchstein National Research Service Award 5F31MH069136-02 (C.M.), Netherlands Organization for Scientific Research NW0-Rubicon Grant 825.07.029 (R.H.), the Canadian Fragile X Foundation fellowships (L.W., M.Z.), Canadian Institutes of Health Research (CIHR) Grants CIHR84256 and CIHR66975, the EJLB-CIHR Michael Smith Chair in Neurosciences and Mental Health and the Canada Research Chair (M.Z.), and the Korea Ministry of Science and Technology under the Creative Research Initiative Program (B.-K.K.) and Brain Research Center Frontier Program (B.-K.K., H.S.). We thank Dr. Jean Richa at the Transgenic and Chimeric Mouse Facility at the University of Pennsylvania for generating transgenic lines and Mark Mayford for the CaMKII $\alpha$ tTA mouse line B.

Correspondence should be addressed to Carolina Isiegas, Bong-Kiun Kaang, or Ted Abel at the above addresses. E-mail: cisiegas@sas.upenn.edu, kaang@snu.ac.kr, or abele@sas.upenn.edu.

DOI:10.1523/JNEUROSCI.2935-07.2008

Copyright $\odot 2008$ Society for Neuroscience $\quad$ 0270-6474/08/286220-11\$15.00/0 adenylyl cyclase, improves memory for passive avoidance tasks in rats (Bernabeu et al., 1997) and for contextual fear conditioning (Barad et al., 1998) and object recognition in mice (Bourtchouladze et al., 2003). However, pharmacological activation of the cAMP pathway in prefrontal cortex impairs working memory (Taylor et al., 1999). Genetic manipulations of several components of the cAMP pathway resulting in elevated cAMP levels by mutation of the cAMP phosphodiesterase, by augmentation of adenylyl cyclase activity, or by altering the expression of G-proteins lead to severe memory impairments in Drosophila (Dudai et al., 1976) and in mice (Pineda et al., 2004; Bourtchouladze et al., 2006). In contrast to these findings, transgenic mice overexpressing type- 1 adenylyl cyclase postnatally that exhibit elevated cAMP levels in forebrain neurons show enhanced memory for object recognition but unaltered fear and spatial memories (Wang et al., 2004). Together, these findings suggest that transient increases in cAMP signaling achieved by pharmacological manipulations may lead to memory enhancement, whereas constitutive upregulation of the pathway has deleterious or null effects on memory formation. Another issue raised by the contradictory findings from pharmacological and genetic studies relates to the cell type in which cAMP acts during memory storage. This is a critical question in light of the reported expression of functional G-protein-coupled receptors linked to cAMP accumulation in glia and interneurons (Milner et al., 2000; Krzan et al., 2001; Farber et al., 2005) and of increasing evidence that astrocytes may modulate synaptic plasticity and thereby modu- 
late memory storage (Allen and Barres, 2005; Pascual et al., 2005; Narita et al., 2006).

To address these issues, a genetic tool is needed that combines the spatial regulation provided by transgenic techniques using cell- and tissue-specific promoters with the greater temporal regulation that is possible using pharmacological approaches. Here, we describe a novel conditional transgenic approach based on the heterologous expression in mice of an Aplysia octopamine receptor, a G-protein-coupled receptor that selectively activates the cAMP/PKA pathway after binding its natural ligand octopamine, leading to transient increases in CAMP levels (Chang et al., 2000). We use this novel inducible system to assess whether acute increases of cAMP selectively in forebrain neurons can improve memory and to define the memory processes during which increasing cAMP signaling may lead to memory enhancement.

\section{Materials and Methods}

Generation of Ap oa ${ }_{1}$ transgenic mice. Bitransgenic mice in which expression of the Ap $\mathrm{oa}_{1}$ was under the control of the CaMKII $\alpha$ promoter combined with the tetracycline responsive system were used in our experiments. To generate mouse lines carrying Ap oa ${ }_{1}$ under the control of the operator sequences to which the tetracycline-controlled transactivator binds, the cDNA encoding Ap oa ${ }_{1}$ was subcloned into the EcoRV site

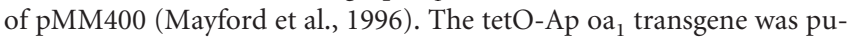
rified away from vector sequences and microinjected into pronuclei of B6/CBA F1 zygotes that were implanted in pseudopregnant females. Founders were backcrossed to C57BL/6J mice. Four tetO-Ap oa ${ }_{1}$ transgenic mouse lines were established. To generate bitransgenic animals, mice from these four lines were crossed to mice from a line that carried the tetracycline-controlled transcriptional transactivator (tTA) driven by the CaMKII $\alpha$ promoter (line B) obtained from Dr. Mark Mayford (The Scripps Research Institute, La Jolla, CA). Reverse transcription (RT)PCR was performed on hippocampus total RNA extracts from bitransgenic mice from the four different tetO-Ap oa ${ }_{1}$ lines to confirm expression of the Ap oa ${ }_{1}$. Further analysis by the in situ hybridization technique revealed expression in one of the four lines (line 3840), and therefore this line was selected for the experiments described in this report. We used 2to 6-month-old male and female bitransgenic mice and wild-type (WT) littermates as controls for all our experiments. For genotyping tTA line B

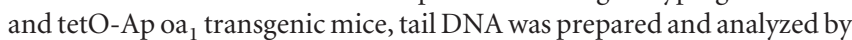
Southern blotting using transgene-specific probes. Mice had ad libitum access to food and water and were maintained on a $12 \mathrm{~h}$ light/dark cycle with behavioral testing occurring during the light phase. All mouse lines were bred onto a C57BL/6J background for more than 10 generations. All experiments were conducted according to National Institutes of Health guidelines for animal care and use and were approved by the Institutional Animal Care and Use Committee of the University of Pennsylvania.

RT-PCR and Nissl staining. For RT-PCR, hippocampi, amygdalae, cortex, striatum, and cerebellum from $\mathrm{Ap} \mathrm{oa}_{1}$ transgenic mice and wild-type littermates were dissected. Total RNA was extracted using Triazol reagent (Invitrogen) and then DNase treated and reverse transcribed with an oligo dT primer. The PCRs were performed for 40 cycles ( 10 cycles: 5 min at $95^{\circ} \mathrm{C}, 10 \mathrm{~s}$ at $98^{\circ} \mathrm{C}, 30 \mathrm{~s}$ at $68 / 66^{\circ} \mathrm{C}$, and $1 \mathrm{~min}$ at $72^{\circ} \mathrm{C} ; 30$ cycles: $10 \mathrm{~s}$ at $98^{\circ} \mathrm{C}, 30 \mathrm{~s}$ at $66^{\circ} \mathrm{C}$, and $1 \mathrm{~min}$ at $\left.72^{\circ} \mathrm{C}\right)$. Ap oa ${ }_{1} \mathrm{cDNA}$ was amplified using the primers Bound-1 (5'-CAGCTGTTGGGGTGTCCACT) and Ap-1 (3'-AGGGAGACGATGAAGAAGTTGGT). Glyceraldehyde-3phosphate dehydrogenase (GAPDH) cDNA was amplified using the primers GAPDH-F (5'-AACTTTGGCATTGTGGAAGG) and GAPDH-R (3'-GGATGCAGGGATGATGTTCT). For detection of Nissl bodies, mouse brains were dissected and flash frozen in 2-methylbutane. Sagittal cryostat sections $(20 \mu \mathrm{m})$ were fixed and stained with thionin.

cAMP assays. Hippocampal slices were prepared as described previously (Abel et al., 1997). Briefly, mice were killed by cervical dislocation, brains were removed, and hippocampi were rapidly dissected in the presence of chilled, oxygenated artificial CSF (aCSF). Acute, transverse hippocampal slices ( $400 \mu \mathrm{m}$ thick) were prepared using a tissue chopper and placed in an interface recording chamber (Fine Science Tools). ACSF, pH
7.4, containing $124 \mathrm{~mm} \mathrm{NaCl}, 4.4 \mathrm{~mm} \mathrm{KCl}, 1.3 \mathrm{~mm} \mathrm{MgSO}_{4}, 1 \mathrm{~mm}$ $\mathrm{NaH}_{2} \mathrm{PO}_{4}, 26.2 \mathrm{~mm} \mathrm{NaHCO} 3,2.5 \mathrm{~mm} \mathrm{CaCl}_{2}$, and $10 \mathrm{~mm}$ D-glucose bubbled with $95 \% \mathrm{O}_{2} / 5 \% \mathrm{CO}_{2}$ was constantly perfused over slices at a rate of $\sim 1 \mathrm{ml} / \mathrm{min}$. Slices were allowed to recover for $\sim 2 \mathrm{~h}$ before the experiments. Application of $100 \mu \mathrm{M}$ octopamine (Sigma) to hippocampal slices was achieved by addition to the perfusion solution. A $10 \mathrm{~mm}$ octopamine stock solution was made in aCSF. To determine cAMP levels in the hippocampal slices, we used a cAMP $\left[{ }^{125} \mathrm{I}\right]$ radioimmunoassay kit (Perkin-Elmer) following the manufacturer's instructions. Briefly, slices were homogenized in $50 \mu \mathrm{l}$ of ice-cold 6\% TCA. TCA extracts were centrifuged at $2500 \times g$ at $4^{\circ} \mathrm{C}$ for $15 \mathrm{~min}$, and supernatants were extracted four times with $5 \times$ volume of water-saturated ether. Etherextracted supernatants were evaporated to dryness in a vacuum system (GMI), and residues were dissolved in $1 \mathrm{ml}$ of buffer and assayed for cAMP levels. The protein pellets were reconstituted in $1 \mathrm{~N} \mathrm{NaOH}$, and the protein content was determined using the Bradford method (Bradford, 1976). cAMP levels are expressed as picomoles per milligram of protein.

cAMP and NeuN immunohistochemistry. Fifteen minutes after intraperitoneal injection of octopamine (1 mg/kg in PBS), mice were anesthetized with ketamine/xylazine and perfused with PBS followed by $4 \%$ paraformaldehyde in PBS. Fixed brains were dissected and then cryoprotected in $30 \%$ sucrose in PBS overnight at $4^{\circ} \mathrm{C}$. Brains were mounted on cryostat chucks using OCT. Coronal sections were cut at a thickness of $30 \mu \mathrm{m}$ and collected in 50\% glycerol in PBS. Floating sections were blocked for $1 \mathrm{~h}$ at room temperature in $2 \%$ normal goat serum (Invitrogen), $1 \%$ bovine serum albumin (GE Healthcare), and $0.2 \%$ Triton X-100 (Sigma) in PBS and then incubated overnight at $4^{\circ} \mathrm{C}$ in blocking solution with rabbit anti-cAMP or mouse anti-NeuN antibodies (1:1000; Millipore Bioscience Research Reagents) and for $2 \mathrm{~h}$ at room temperature with goat anti-rabbit IgG-Alexa488 (1:250; Invitrogen) or goat anti-mouse IgG-cy3 (1:250; GE Healthcare). Sections were washed three times for 5 min each in PBS before and after each incubation step. Sections were mounted on slides in Vectashield mounting medium with DAPI (Vector Laboratories) and imaged using a Zeiss LSM510 NLO confocal microscope using a $10 \times$ objective and an AxioCam digital microscope camera (Zeiss).

pCREB immunohistochemistry. Thirty minutes or $2 \mathrm{~h}$ after intraperitoneal injection of octopamine ( $1 \mathrm{mg} / \mathrm{kg}$ in PBS), mice were anesthetized with isoflurane and perfused with PBS followed by $4 \%$ paraformaldehyde in PBS. Fixed brains were dissected and then cryoprotected in 30\% sucrose in PBS for $2 \mathrm{~d}$ at $4^{\circ} \mathrm{C}$. Brains were mounted on cryostat chucks using OCT. Coronal sections were cut at a thickness of $25 \mu \mathrm{m}$, collected, and stored in PBS with $0.1 \%$ sodium-azide. After rinsing in PBS $(3 \times)$ and incubation in $0.3 \% \mathrm{H}_{2} \mathrm{O}_{2}(30 \mathrm{~min})$ followed by rinsing in $\mathrm{PBS}(3 \times)$, sections were preincubated in $5 \%$ normal goat serum (Jackson ImmunoResearch Laboratories) in PBS for $20 \mathrm{~min}$ at room temperature. After preincubation, sections were incubated with rabbit-anti-pCREB IgG (1: 2000; Millipore) or rabbit anti-pCREB IgG (1:200; Affinity BioReagents) in $1 \%$ normal goat serum, $0.3 \%$ Triton $\mathrm{X}-100$, and $0.1 \%$ azide in PBS at room temperature for $48 \mathrm{~h}$. Sections were then rinsed in PBS $(3 \times)$ and incubated for $3 \mathrm{~h}$ with biotinylated goat-anti-rabbit IgG (1:500; Jackson ImmunoResearch Laboratories) or with goat anti-rabbit IgG and HRPlinked antibody (1:200; Cell Signaling Technology) in PBS containing $0.3 \%$ Triton X-100 and $1 \%$ normal goat serum at $5^{\circ} \mathrm{C}$. After rinsing with PBS $(3 \times)$, sections were incubated with the avidin-biotin-horseradish peroxidase complex (1:500; ABC kit; Vector Laboratories) in PBS containing $0.3 \%$ Triton $\mathrm{X}-100$ for $2 \mathrm{~h}$ at room temperature. Finally after rinsing in PBS for half a day, sections were processed with diaminobenzidine $(0.02 \%$ in Tris- $\mathrm{HCl}, \mathrm{pH} 7.6)$ with $100 \mu \mathrm{l}$ of $0.1 \% \mathrm{H}_{2} \mathrm{O}_{2}$ as a reaction initiator. After $5 \mathrm{~min}$, the reaction was stopped by washing the sections with PBS. Sections were mounted with gelatin $(0.7 \%)$ and dried for $24 \mathrm{~h}$. The mounted sections were then dehydrated using ethanol and xylene, coverslipped with DPX (Merck), and dried for $24 \mathrm{~h}$.

Quantification. Images of the dorsal CA1 region of the hippocampus were taken using a Fisher Micromaster microscope with camera. Optical densities (ODs) of pCREB immunoreactivity were measured in the CA1 region of the dorsal hippocampus (five slices per animal, three animals per group) using ImageJ image analysis software. The OD is expressed in arbitrary units corresponding to gray levels. The value of background labeling was measured in the stratum radiatum of each individual section 
and subtracted from the OD value in the stratum pyramidale in area CA1 to account for variability in background staining among sections.

Electrophysiological analysis. To examine basal synaptic transmission and long-term potentiation (LTP), hippocampal slices were prepared as described in the previous section. Field EPSPs (fEPSPs) were elicited in CA3 axons with a bipolar stimulating electrode $(0.5 \mathrm{~mm}$; A-M Systems) and recorded using a glass micropipette (1.5 mm OD; A-M Systems) electrode filled with aCSF with a resistance of $2-4 \mathrm{M} \Omega$, placed in the stratum radiatum of CA1. Data were acquired using ClampEx 9.2 and a Digidata 1322 analogto-digital converter (Molecular Devices) at $20 \mathrm{kHz}$ and low-pass filtered at 2 $\mathrm{kHz}$ with a four-pole Bessel filter. Input-output curves were generated by measuring the initial slope of the fEPSP in response to systematic increases in the strength of the stimulus. Slices that had maximum amplitude responses of $<4 \mathrm{mV}$ were rejected. The stimulus strength was then set to elicit $\sim 40 \%$ of the maximum response. For LTP experiments, test pulses were delivered to Schaffer collaterals once every minute for $15 \mathrm{~min}$. Slices that did not have stable baseline responses for $15 \mathrm{~min}$ were rejected. To determine the effects of octopamine on LTP induced using a single $1 \mathrm{~s}, 100 \mathrm{~Hz}$ train of stimuli, octopamine $(100 \mu \mathrm{M}$, in $0.1 \% \mathrm{w} / \mathrm{v}$ ascorbic acid) or vehicle $(0.1 \% \mathrm{w} / \mathrm{v}$ ascorbic acid) was added to the perfusate for 5 or $30 \mathrm{~min}$ starting at minute 16 . The single $1 \mathrm{~s}, 100 \mathrm{~Hz}$ train of stimuli was delivered at minute 20 or 30 , and synaptic responses to the test pulse were followed for $2 \mathrm{~h}$ after the tetanus. Octopamine or vehicle were washed out $1 \mathrm{~min}$ after delivering the tetanus.

For depotentiation experiments, a single $1 \mathrm{~s}, 100 \mathrm{~Hz}$ stimulus was delivered in the stratum radiatum of CA1 area, followed by a lowfrequency stimulus of $5 \mathrm{~Hz}$ for $3 \mathrm{~min}$ to elicit depotentiation $5 \mathrm{~min}$ after the tetanus. Octopamine or vehicle was perfused for $4 \mathrm{~min}$ right before the tetanus and was washed out $1 \mathrm{~min}$ after.

For whole-cell patch-clamp experiments, mice were anesthetized with $1-2 \%$ halothane. Coronal hippocampal slices $(300 \mu \mathrm{m})$ were prepared using standard method (Zhao et al., 2005). Slices were transferred to a room temperature submerged recovery chamber with oxygenated $(95 \%$ $\mathrm{O}_{2}$ and $5 \% \mathrm{CO}_{2}$ ) solution containing the following: $124 \mathrm{~mm} \mathrm{NaCl}, 25 \mathrm{~mm}$ $\mathrm{NaHCO}_{3}, 2.5 \mathrm{~mm} \mathrm{KCl}, 1 \mathrm{~mm} \mathrm{KH} \mathrm{PO}_{4}, 2 \mathrm{~mm} \mathrm{CaCl}_{2}, 2 \mathrm{~mm} \mathrm{MgSO}_{4}$, and 10 $\mathrm{mm}$ glucose. After $1 \mathrm{~h}$ recovery, slices were placed in a recording chamber on the stage of an Axioskop 2FS microscope (Zeiss) equipped with infrared differential interference contrast optics for visualized whole-cell patch-clamp recordings. EPSCs were recorded from CA1 pyramidal neurons with an Axon 200B amplifier (Molecular Devices), and stimulations were delivered by a bipolar tungsten stimulating electrode placed in the Schaffer collateral afferents. Recording electrodes (2-5 M $\Omega$ ) contained a pipette solution composed of the following: $120 \mathrm{~mm} \mathrm{~K}$-gluconate, $5 \mathrm{~mm}$ $\mathrm{NaCl}, 1 \mathrm{~mm} \mathrm{MgCl} 2,0.5$ mм EGTA, 2 mm Mg-ATP, $0.1 \mathrm{~mm} \mathrm{Na}_{3} \mathrm{GTP}$, and $10 \mathrm{~mm}$ HEPES, pH $7.2(280-300 \mathrm{mOsmol})$. To examine the voltage dependence of EPSCs, Cs-gluconate was used to replace the K-gluconate. Access resistance was 15-35 M $\Omega$ and was monitored throughout the experiment. Data were discarded if access resistance changed $>10 \%$ during an experiment. The membrane potential was held at $-65 \mathrm{mV}$ throughout the experiment.

Surgeries and intracerebroventricular infusions. Mice were anesthetized with isoflurane, placed in a stereotaxic frame (David Kopf Instruments), and implanted with a 22 gauge guide cannula (Plastics One) into the lateral ventricle [anteroposterior from the bregma, $-0.4 \mathrm{~mm}$; lateral, 1.1 mm; depth, 2.3 mm (Franklin and Paxinos, 1997)]. After surgery, mice were singly housed and allowed to recover for 1 week. On days 5 and 6 (after surgery), mice were gently handled. On day 7 (after surgery), mice were injected intracerebroventricularly by placing a needle through the guide cannula, which was connected to a microsyringe (Hamilton) via a polyethylene tube. Drug ( $100 \mu \mathrm{g}$ octopamine in $3 \mu \mathrm{l}$ of PBS) or vehicle (3 $\mu \mathrm{l}$ of PBS) were delivered over a $1 \mathrm{~min}$ window, using a microinfusion pump (Harvard Apparatus), and the needle remained in place an additional $30 \mathrm{~s}$ to allow for diffusion of the drug. After the experiment, animals were killed, and their brains were coronally sectioned with a cryostat to verify cannula placement.

Fear conditioning. Fear conditioning experiments were performed in standard conditioning chambers (Med Associates). Mice were handled for $2 \mathrm{~min}$ for 2 consecutive days before contextual fear conditioning. On the day of acquisition, mice were placed in the conditioning chamber and after 2.28 min received a mild $2 \mathrm{~s}, 0.75 \mathrm{~mA}$ footshock. In experiments involving intracerebroventricular infusions, mice received a milder, 0.4 $\mathrm{mA}$ footshock. Mice were left in the chamber for additional $30 \mathrm{~s}$ before returning to the home cage. No tone was played at any time. Freezing behavior [defined as complete immobility except for breathing (Fanselow, 1980)] was scored during the 3 min training session. During testing, $1 \mathrm{~h}$ (short-term memory) or $24 \mathrm{~h}$ after training (long-term memory), mice were placed back in the conditioning chamber for $3 \mathrm{~min}$, and freezing behavior was scored. Different sets of mice were used for the 1 and $24 \mathrm{~h}$ retention tests.

To test the effects of intracerebroventricular octopamine infusions on the early stage of memory consolidation, mice were infused vehicle or octopamine immediately after training and returned to the home cage until the time of testing. To examine the effects of intracerebroventricular octopamine infusions on the late memory consolidation period, mice were trained as previously described and returned to the home cage, and $3 \mathrm{~h}$ after training, mice were infused vehicle or octopamine as described and returned to the home cage until testing. In all cases, mice were tested $24 \mathrm{~h}$ after training by placing them back in the conditioning chamber for $3 \mathrm{~min}$. Freezing was scored during the $3 \mathrm{~min}$ testing session.

Object recognition. The object-recognition task consisted of a training phase and a testing phase. Before training, all mice were handled for 5 min per day for $4 \mathrm{~d}$ and habituated to the experimental apparatus for 4 consecutive days with $15 \mathrm{~min}$ of exploration in the absence of objects. During the training phase (15 $\mathrm{min})$, mice were placed in the experimental apparatus (a white square open field $40 \times 40 \times 40 \mathrm{~cm}$ ) with two identical objects placed $20 \mathrm{~cm}$ apart. After a retention interval of $24 \mathrm{~h}$, mice were placed back into the square environment for the testing phase. Two objects were again present, but one of the familiar objects was now replaced with a novel one. Mice were again allowed to freely explore the environment and the objects for $10 \mathrm{~min}$. All testing and training sessions were videotaped and analyzed by an individual blind to the genotype of the animals examined. A mouse was scored as exploring an object whenever any part of its body other than the tail was touching the object or whenever it was within $1 \mathrm{~cm}$ of the object and facing it. Measurement of the time exploring each object was recorded and expressed as the percentage of time spent exploring the novel object relative to the total time spent exploring both of the objects. The identity of the objects (which one was novel and which one was familiar), as well as the spatial location in which the novel and familiar objects were located, was counterbalanced between subjects.

Data analysis. Student's $t$ test were used to analyze cAMP assays data, pCREB immunohistochemistry data, and behavioral data. Repeatedmeasures ANOVAs were used to analyze the LTP and depotentiation data using SigmaStat (version 2.03; Systat Software) and Statistica 7 (StatSoft). When significant interactions were found for ANOVAs, post hoc comparisons were made using Student-Newman-Keuls range statistics. Significance was established at $p<0.05$. All data are expressed as mean \pm SEM. Experimenters were blind to genotype, and genotypes were confirmed by Southern blot analysis after biochemical, behavioral, and electrophysiological tests.

\section{Results}

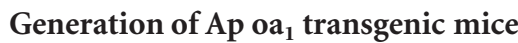

In invertebrates, octopamine is a biogenic amine neurotransmitter that mediates diverse functions in motor control and behavior through activation of specific octopamine GPCR receptors dispersed in the CNS (Farooqui, 2007). In vertebrates, octopamine is a trace amine considered a metabolic byproduct of catecholamine synthesis. Its physiological/pathological relevance is unknown, but its endogenous levels in the rodent brain are several hundredfold below those of the classical neurotransmitters dopamine, norepinephrine, and 5-hydroxytryptamine (Berry, 2004). The expression of an Aplysia octopamine receptor $\left(\mathrm{Ap} \mathrm{oa}_{1}\right)$ in a human cell line (HEK-293) selectively stimulated cAMP synthesis after transient application of the natural ligand octopamine, whereas dopamine or serotonin had little or no appreciable effect in the activation of the receptor (Chang et al., 2000). Moreover, the 10 known isoforms of 
the mouse adrenergic receptors expressed in $\mathrm{CHO}$ (Chinese hamster ovary) cells were poorly activated by octopamine as determined by cAMP levels, suggesting high selectivity of the octopamine ligand (Zhang et al., 2004). Based on this evidence, we reasoned that this adenylyl cyclase-coupled octopamine receptor would be an ideal tool to conditionally achieve acute increases of cAMP signaling in the mouse brain (Fig. 1A).

To target expression of Ap oa ${ }_{1}$ to neurons within forebrain structures, we used the CaMKII $\alpha$ promoter combined with the tetracycline responsive system. One transgenic mouse line carried the tTA driven by the CaMKII $\alpha$ promoter; these mice are referred to as CaMKII $\alpha$-tTA line B or tTA(B) mice (Mayford et al., 1996). These tTA(B) mice were crossed to transgenic mice that carried the Ap oa ${ }_{1}$ transgene driven by the tet-O-promoter. Crossing transgenic mice from both mouse lines gave rise to double transgenics referred to as Ap oa transgenic mice (Fig. $1 B$ ). We examined expression of the receptor by RT-PCR in different

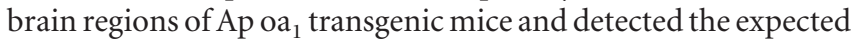
315 bp band in hippocampus, amygdala, cortex, and striatum, but not in cerebellum (Fig. 1C, top). In contrast, this band was not detected in any of these brain regions from wild-type littermates (Fig. 1C, top) or in control reactions in which reverse transcriptase was not added (data not shown). To verify that expression of Ap oa ${ }_{1}$ receptor only occurs when both the tTA and

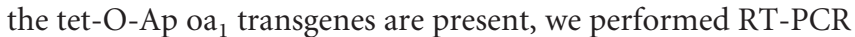
in hippocampus from wild-type, single tTA, single tetO-Ap oa ${ }_{1}$, and Ap oa ${ }_{1}$ transgenic mice (Fig. 1C, bottom). We found the

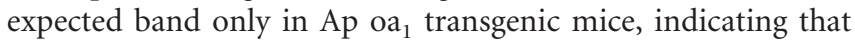
expression of the Ap oa $\mathrm{a}_{1}$ transgene results from expression of the transactivator tTA driven by the CaMKII $\alpha$ promoter. Nissl stain-

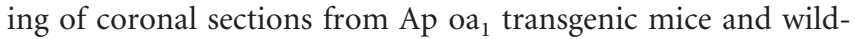
type littermates showed no gross morphological differences (data not shown).

Given that cAMP signaling pathways in the hippocampus are critically required for the formation of certain types of memory (Bernabeu et al., 1997; Wong et al., 1999), and that cAMP increases mediate various forms of hippocampus synaptic plasticity thought to underlie memory storage (Chetkovich et al., 1991; Chetkovich and Sweatt, 1993; Frey et al., 1993), we investigated the functionality of the Ap $\mathrm{oa}_{1}$ receptor by measuring cAMP levels in hippocampal slices from Ap oa ${ }_{1}$ transgenic mice after bath application of $100 \mu \mathrm{M}$ octopamine. This concentration was chosen because it led to maximal activation of the Ap oa $\mathrm{a}_{1}$ receptor, as measured by cAMP levels in mammalian cells (Chang et al., 2000), and because it is in the range at which other GPCR agonists such as the $\beta$-adrenergic receptor agonist isoproterenol have effectively elicited increases in cAMP in hippocampal slices (Chetkovich et al., 1991; Chetkovich and Sweatt, 1993). We found that CAMP levels significantly increased after bath application of octopamine for $5 \mathrm{~min}$ in $\mathrm{Ap} \mathrm{oa}_{1}$ transgenic mice (1674 \pm 288 pmol of cAMP per mg protein vs $962 \pm 57$ pmol of cAMP per mg protein for octopamine vs vehicle treated slices; Student's $t$ test; $p=0.04$ ). In contrast, cAMP levels did not significantly change in hippocampal slices from wild-type controls after octopamine administration ( $1153 \pm 88$ pmol of cAMP per mg protein vs $939 \pm 102$ pmol of cAMP per mg protein for octopamine vs vehicle treated slices; Student's $t$ test; $p=0.11$, NS) (Fig. 1D). Longer bath application (15 $\mathrm{min}$ ) of octopamine resulted in less of an increase in cAMP levels than that observed after $5 \mathrm{~min}$, suggesting a peak response in cAMP elevation 5 min after Ap oa activation (data not shown). To assess the in vivo activation of Ap

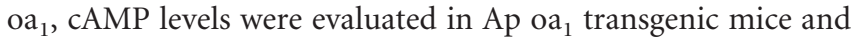
wild-type littermates $15 \mathrm{~min}$ after intraperitoneal injection of octopamine (1 mg/kg) using immunohistochemistry. We found that octopamine injection increased cAMP levels in Ap oa trans- $^{-}$ genic mice compared with control littermates in the CA3 and CA1 regions of the hippocampus (Fig. $1 E$, top). To verify neuronal expression of the Ap oa 1 receptor, we performed cAMP and NeuN coimmunohistochemistry in hippocampal sections from Ap $\mathrm{oa}_{1}$ transgenic mice. We found colocalization of the signal, confirming neuronal expression of the heterologous receptor as expected based on the use of the CaMKII $\alpha$ promoter (Fig. $1 E$, bottom). The transcription factor cAMP-responsive elementbinding protein (CREB) is one of the downstream targets of cAMP known to play a key role in hippocampal synaptic plasticity and in memory formation (Josselyn and Nguyen, 2005). To determine whether CREB phosphorylation at the serine 133 site was enhanced in Ap oa mice after activation of the octopamine receptor, pCREB levels were assessed in the hippocampus from Ap oa ${ }_{1}$ transgenic mice and littermate controls (single transgenics and wild types) $30 \mathrm{~min}$ and $2 \mathrm{~h}$ after intraperitoneal injection of octopamine (1 $\mathrm{mg} / \mathrm{kg})$ using immunohistochemistry (Fig. $1 F, G)$. pCREB immunostaining was of greater intensity in CA1 and CA3 pyramidal neurons and in dentate gyrus granular cells from Ap oa mice than in controls. In agreement with the 50\% increase in cAMP levels observed in the hippocampal slices from Ap oa ${ }_{1}$ mice after bath application of octopamine (Fig. 1D), quantification of pCREB levels in CA1 region of the hippocampus revealed a significant $33 \%$ increase in $\mathrm{Ap} \mathrm{oa}$ mice compared with controls $30 \mathrm{~min}$ after octopamine injection [OD (percentage of control): controls ( $n=3,5$ sections per mouse), $100 \pm 5.20 \%$; Ap oa 1 ( $n=3,5$ sections per mouse), $133.46 \pm 7.78 \%$; Student's $t$ test, $p<0.05$ ], and a significant $57.9 \%$ increase in pCREB levels $2 \mathrm{~h}$ after octopamine injection [OD (percentage of control): Ap $\mathrm{oa}_{1} /$ vehicle $(n=4,10$ sections total), $100 \pm 1.84 \%$; Ap oa 1 octopamine ( $n=3,8$ sections total), $157.9 \pm 16.05 \%$; Student's $t$ test, $p<0.01]$. These data show that the increase in cAMP levels and cAMP signaling selectively detected in Ap oa ${ }_{1}$ transgenic mice is attributable to conditional activation of the heterologously expressed receptor after binding its natural ligand.

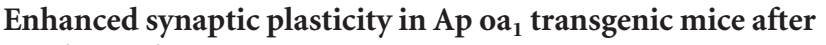 conditional receptor activation}

LTP, the activity-dependent increase in the strength of neuronal connections, is a form of long-lasting synaptic plasticity that has been proposed as a cellular mechanism of learning and memory (Maren, 2005). Various studies report that cAMP levels rise transiently after induction of LTP in hippocampal slices (Chetkovich et al., 1991; Chetkovich and Sweatt, 1993; Frey et al., 1993), and a form of LTP resulting from a single $1 \mathrm{~s}, 100 \mathrm{~Hz}$ train [early LTP (E-LTP) (Duffy et al., 2001)] is enhanced when the tetanus is delivered during pharmacological (Barad et al., 1998; Gelinas and Nguyen, 2005) or genetic (Wang et al., 2004) elevation of cAMP levels in hippocampal slices. Given these studies and our biochemical data showing an increase in hippocampal cAMP levels after octopamine application in Ap oa mice (Fig. $1 E$ ), we hypothesized that hippocampal slices from these mice would show enhanced synaptic plasticity in the presence of octopamine. Before examining changes in LTP, we assessed basal synaptic properties in hippocampal slices from Ap oa mice (Fig. 2). Field potentials in the CA1 region of hippocampi from Ap oa trans- $_{1}$ genic mice and wild-type littermates were elicited with bipolar stimulating electrodes placed in the Schaffer collaterals and characterized with respect to input-output relationship. We found that input-output curves relating presynaptic fiber volley amplitude to the initial slope of the corresponding fEPSP were not 
A

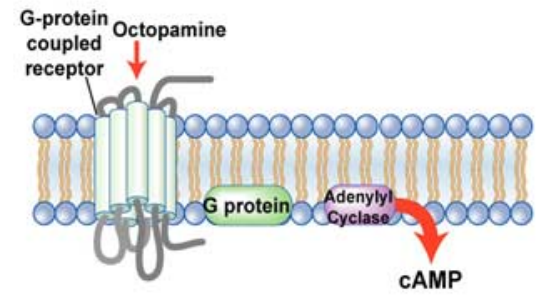

B

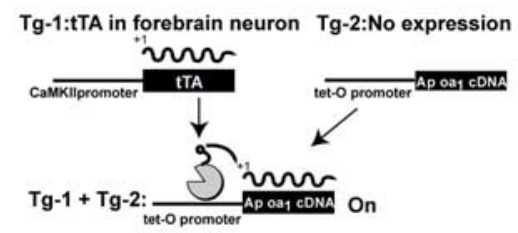

C
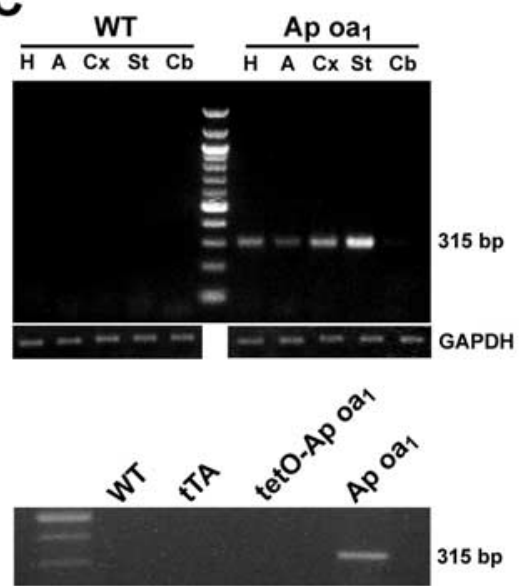

D

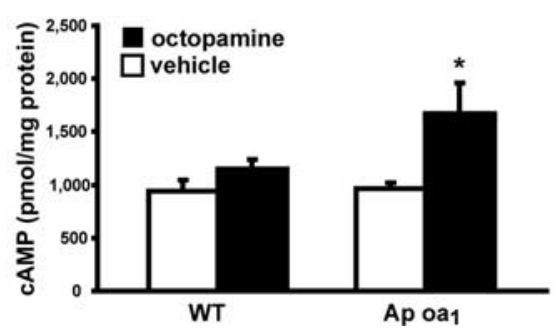

Figure 1. Conditional activation of the Ap $0 \mathrm{a}_{1}$ expressed in mouse forebrain neurons leads to increases in cAMP levels. $A, A p$ $0 \mathrm{a}_{1}$ is a G-protein-coupled receptor whose activation by octopamine stimulates adenylyl cyclase activity, which in turn synthesizes cAMP. $B$, Schematic of the generation of bitransgenic mice expressing Ap oa ${ }_{1}$ [modified with permission from Mayford et al. (1996), their Fig. 1A]. Two different transgenic lines are used: one expressing tTA under the control of the CaMKIl $\alpha$ promoter (Mayford et al., 1996) and another carrying the Ap oa ${ }_{1}$ CDNA under the control of tet operator sequences (tet0 promoter). Expression of $A p 0 a_{1}$ occurs in mice bearing both transgenes. $C$, Top, RT-PCR showing expression of the Ap od $\mathrm{a}_{1}$ transgene in the hippocampus (H), amygdala (A), cortex (CX), and striatum (St) in Ap oa transgenic mice, but not in WT mice. Ap oa ${ }_{1}$ transgene is not expressed in the cerebellum (Cb) in Ap oa ${ }_{1}$ transgenic mice nor in wild-type mice. Middle, The RT-PCR product corresponding to the GAPDH control in these regions. Bottom, RT-PCR showing expression of the $A p$ od ${ }_{1}$ transgene in the hippocampus from Ap oa $a_{1}$ transgenic mice but not in WT, single TTA, and single tet0-Ap o $a_{1}$ transgenics. D, Determination of cAMP levels in hippocampal slices from Ap oa ${ }_{1}$ transgenic mice ( $n=10-14$ slices from 3 mice) and WT littermates ( $n=13-14$ slices from 3 mice) after 5 min of vehicle (open bars) or $100 \mu$ m octopamine (filled bars) application reveals selective conditional activation of the Ap oa 1 receptor after octopamine binding that leads to a $50 \%$ significant increase in cAMP levels. Values are mean \pm SEM. ${ }^{*} p<0.05$. $E$, Top, Immunohistochemistry reveals that cAMP levels increase in hippocampus of Ap oa ${ }_{1}$ transgenic mice 15 min after intraperitoneal administration of octopamine. Representative sections from $A p ~ 0 a_{1}$ transgenic mice intraperitoneally injected with octopamine show higher levels of CAMP in hippocampus areas CA3 and CA1 than wild-type littermates that received an intraperitoneal injection of octopamine. Scale bars, $200 \mu \mathrm{m}$. Bottom, Coimmunostaining reveals colocalization of CAMP and NeuN signals (Merge) in hippocampal sections from Ap oa ${ }_{1}$ mice, indicating neuronal expression of the heterologous

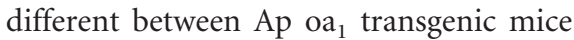
and wild-type littermates (Fig. 2A), and that maximum initial slopes of fEPSPs in Ap oa ${ }_{1}$ transgenic mice and wild-type controls were similar $\left(\mathrm{Ap} \mathrm{oa}_{1}, 4.32 \pm 0.53\right.$; WT, $4.79 \pm 0.45)$, suggesting that basal synaptic transmission is normal in Ap oa transgenic $_{1}$ mice.

Using whole-cell patch-clamp recordings, we examined neuronal excitability and glutamatergic excitatory neurotransmission in CA1 pyramidal neurons of Ap oa transgenic and wild-type mice. We found no differences between wild-type and Ap $\mathrm{oa}_{1}$ transgenic mice in the number of spikes elicited in response to current injections of either 50 or 100 pA (Fig. 2 B, C). In addition, there was no difference in the resting membrane potential between neurons from wild-type $(-62.6 \pm 1.6 \mathrm{mV})$ and $\mathrm{Ap} \mathrm{oa}$ transgenic $(-64.0 \pm 1.5 \mathrm{mV})$ mice. We also examined excitatory synaptic transmission from Schaffer collateral afferents to CA1 pyramidal neurons. To assess the voltage dependence of AMPA receptor- and NMDA receptor-mediated EPSCs, we recorded synaptic currents over a range of membrane potentials from $-85 \mathrm{mV}$ to +55 $\mathrm{mV}$. AMPA receptor EPSCs showed a linear $I-V$ relationship with the reversal potential $\sim 0 \mathrm{mV}$, and there was no difference between $\mathrm{Ap} \mathrm{oa}$ transgenic and wild-type mice in the slope and reversal potential of AMPA receptor EPSCs (Fig. 2D). NMDA receptor EPSCs showed a typical, rectified $I-V$ relationship with the reversal potential $\sim 0 \mathrm{mV}$, and no difference was found for the $I-V$ relationship of NMDA receptor EPSCs between Ap oa 1 transgenic and wild-type mice (Fig. 2E). Together, these data indicate that basal synaptic transmission, neuronal excitability, and glutamatergic excitatory neurotransmission are normal in Ap oa $\mathrm{o}_{1}$ transgenic mice.

To test our hypothesis that Ap oa ${ }_{1}$ activation would enhance long-term potentiation, hippocampal slices from Ap oa ${ }_{1}$ and wild-type mice were subjected to a single train of tetanic stimulation after a $4 \mathrm{~min}$

receptor. Scale bar, $200 \mu \mathrm{m}$. $\boldsymbol{F}$, Top, Immunohistochemistry shows that $p$ CREB levels are higher in hippocampus from $A p$ $0 \mathrm{a}_{1}$ mice than in controls (single transgenics and wild types) 30 min after intraperitoneal injection of octopamine. Scale bars, $300 \mu \mathrm{m}$. Bottom, A detailed view from hippocampal CA1 region showing increased $p C R E B$ immunostaining in CA1 pyramidal neurons from $A p 0 a_{1}$ mice compared with controls. Scale bars, $30 \mu \mathrm{m}$. G, Representative view from hippocampal CA1 region showing increased $p C R E B$ immunostaining in CA1 pyramidal neurons from $A p 0 a_{1}$ mice $2 \mathrm{~h}$ after intraperitoneal injection of octopamine compared with $\mathrm{Ap}_{\mathrm{oa}} \mathrm{a}_{1}$ mice injected with vehicle. Scale bar, $20 \mu \mathrm{m}$. 


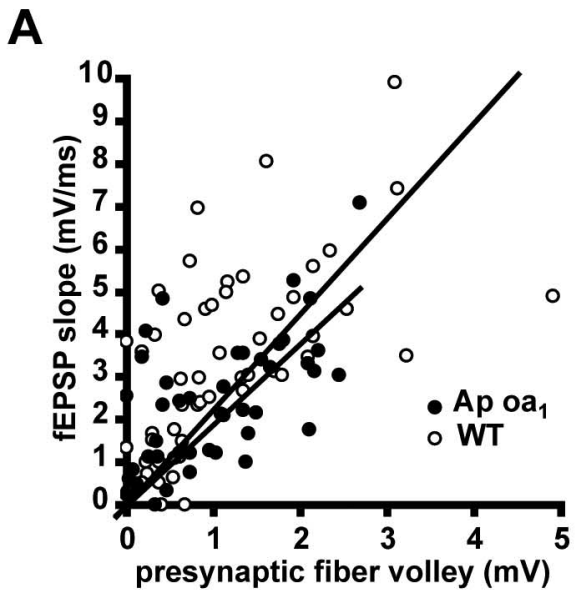

B

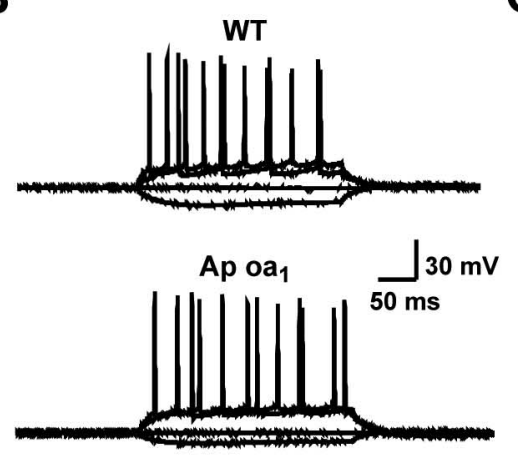

C

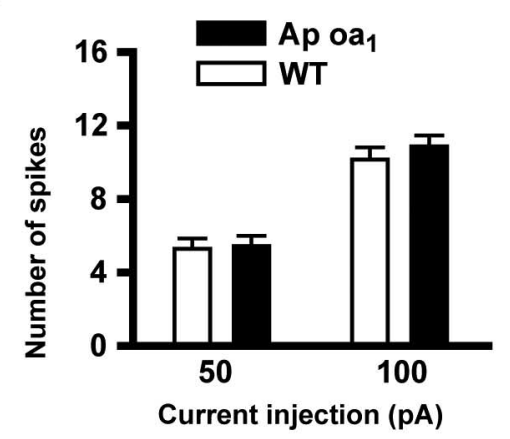

D

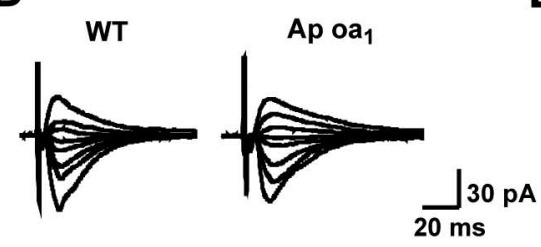

E
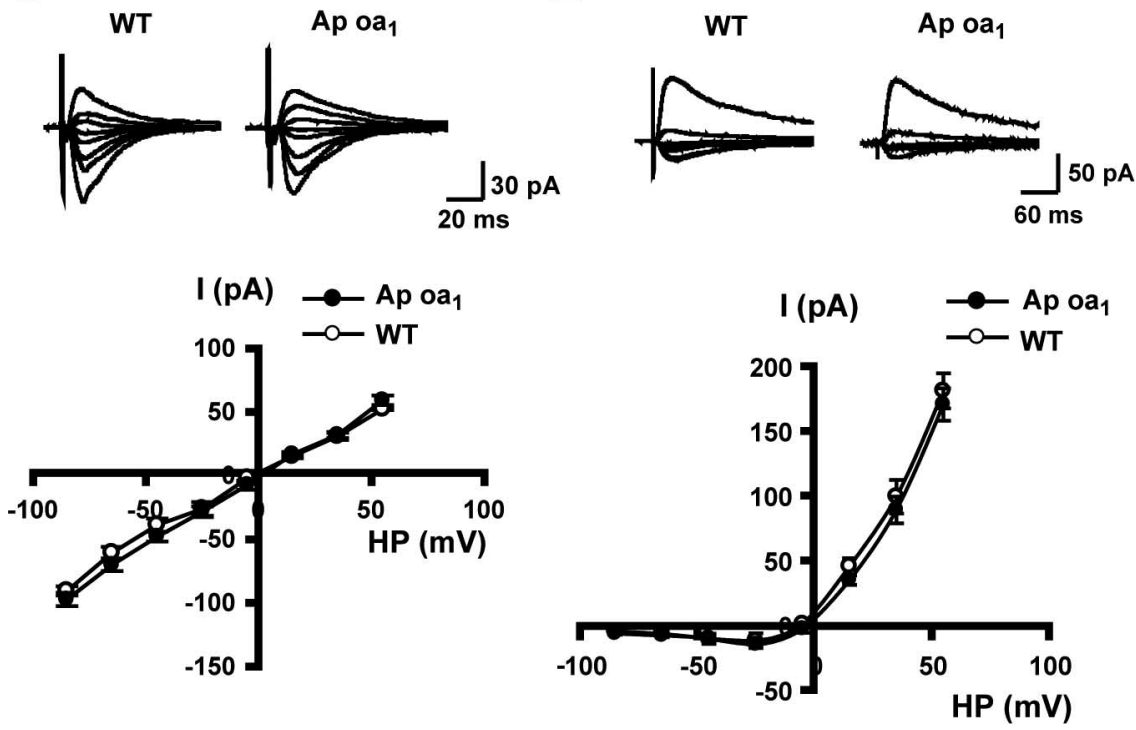

Figure 2. Baseline electrophysiological properties and neuronal excitability are normal in Ap oa ${ }_{1}$ transgenic mice. $\boldsymbol{A}$, Inputoutput curves relating presynaptic fiber volley amplitude to the initial slope of the corresponding fEPSP are not different between Ap oa 1 transgenic mice ( $n=3$ slices from 3 mice) and WT littermates ( $n=3$ slices from 3 mice). $B$, Sample traces show that current injection from $-50 \mathrm{pA}$ to $100 \mathrm{pA}$ with $50 \mathrm{pA}$ steps for $400 \mathrm{~ms}$ induces repetitive action potentials in neurons of Ap $0 \mathrm{a}_{1}$ transgenic mice and WT littermates. $C$, There is no significant difference in the numbers of spikes with either 50 or $100 \mathrm{pA}$ injected current between Ap oa ${ }_{1}$ transgenic mice ( $n=7$ neurons from 5 mice) and WT littermates ( $n=7$ neurons from 5 mice). $D$, Current over a range of membrane potentials from -85 to $+55 \mathrm{mV}$ shows no differences in $/-V$ curve of AMPA receptormediated EPSC in Ap oa ${ }_{1}$ transgenic mice ( $n=7$ neurons from 5 mice) and WT littermates ( $n=9$ neurons from 6 mice). Insets, The AMPA receptor EPSCs at holding potentials from -85 to $+55 \mathrm{mV}$ in Ap $0 \mathrm{a}_{1}$ transgenic mice and wild-type littermates. $\boldsymbol{E}$ No difference in $/-V$ curve of NMDA receptor-mediated EPSC is observed between Ap oa transgenic mice ( $n=7$ neurons from 5 mice) and WT littermates ( $n=9$ neurons from 6 mice). Insets, The NMDA receptor EPSCs at holding potentials from -70 to $+40 \mathrm{mV}$ in Ap oa ${ }_{1}$ transgenic mice and wild-type littermates. Values are mean \pm SEM. HP, Holding potential. application of $100 \mu \mathrm{M}$ octopamine. In slices from Ap oa 1 transgenic mice, we found statistically significant larger E-LTP than in control slices exposed to vehicle and than in hippocampal slices from wild-type mice exposed to octopamine or vehicle (Fig. 3A), with average potentiation at $60 \mathrm{~min}$ at $215 \pm 16 \%$ of baseline for octopamineincubated slices, $146 \pm 14 \%$ of baseline for vehicle incubated slices, and $126 \pm 9 \%$ and $130 \pm 7 \%$ of baseline for wild-type hippocampal slices exposed to octopamine and vehicle, respectively (Fig. $3 B$ ) (two-way repeated-measures ANOVA, $F_{(1,31)}=$ $11.785 ; p=0.00171$; post hoc Student-Newman-Keuls: octopamine-incubated Ap oa transgenic slices compared with vehicle incubated, $p=0.000385$; compared with wild-type slices incubated with octopamine, $p=0.000170$, and with vehicle, $p=$ 0.000130). Moreover, fEPSP slopes remained significantly elevated for at least $2 \mathrm{~h}$ selectively in octopamine exposed slices from Ap oa 1 transgenic mice (Fig. $3 A$ ), with average potentiation at $120 \mathrm{~min}$ at $198 \pm$ $22 \%$ of baseline. In contrast, fEPSPs returned to baseline levels in hippocampal

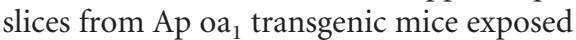
to vehicle $(98 \pm 9 \%$ of baseline) and from wild-type mice incubated with octopamine (111 $\pm 8 \%$ of baseline) or vehicle (104 \pm $4 \%$ of baseline), indicating that binding of octopamine to its specific receptor is necessary to cause the enhancement of this form of LTP (Fig. 3B) (two-way repeatedmeasures ANOVA, $F_{(1,30)}=10.664 ; p=$ 0.00273; post hoc Student-Newman-Keuls: octopamine-incubated Ap oa ${ }_{1}$ transgenic slices compared with vehicle incubated, $p=$ 0.000168; compared with wild-type slices incubated with octopamine, $p=0.000144$, and with vehicle, $p=0.000176$ ). Bath application of $100 \mu \mathrm{M}$ octopamine in the absence of tetanus had no effect on basal synaptic responses of hippocampal slices from Ap $\mathrm{oa}_{1}$ mice (Fig. 3A), in agreement with pharmacological studies showing that the type IV phosphodiesterase inhibitor rolipram alone has no effect on basal synaptic responses to stimulation of the Schaffer collateral pathway in hippocampal slices (Barad et al., 1998), and with previous work reporting normal basal neural transmission in transgenic mice overexpressing type I adenylyl cyclase with increased hippocampal cAMP levels (Wang et al., 2004). These results demonstrate that the activation of Ap $\mathrm{oa}_{1}$ causes the larger and longer-lasting E-LTP observed in the Ap oa mice.

Depotentiation is a form of synaptic depression that can be elicited during early stages of LTP (Zhuo et al., 1999). It has been reported that facilitated E-LTP induced us- 
A
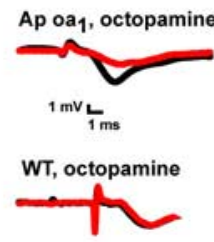

$1 \mathrm{mv}$ L $\mathrm{ms}$

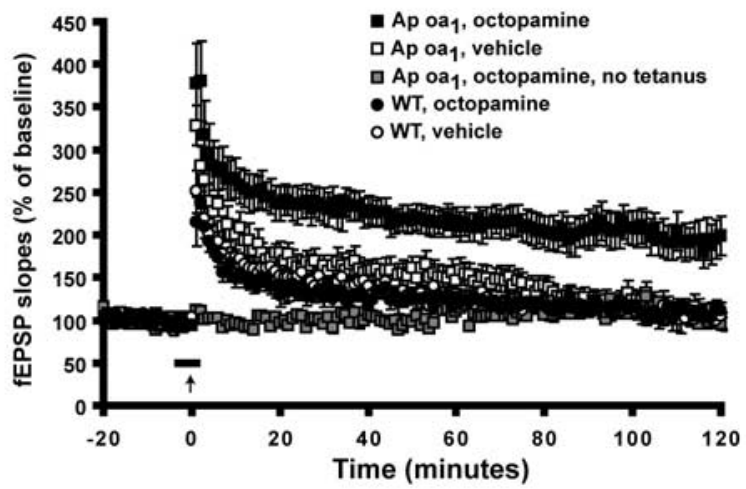

B

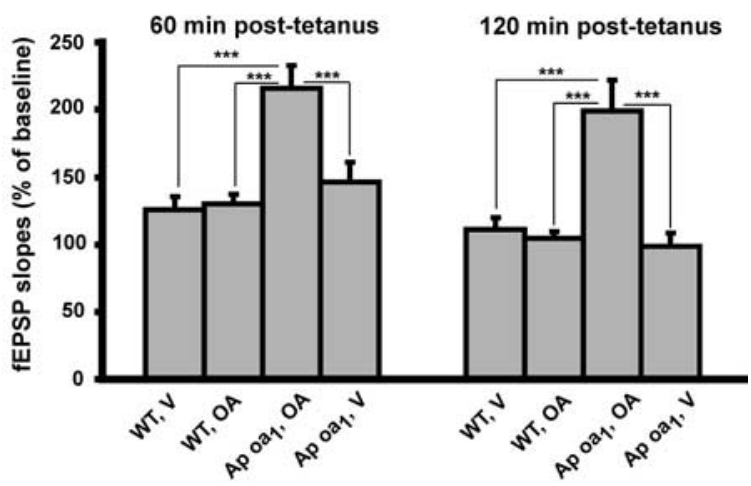

C

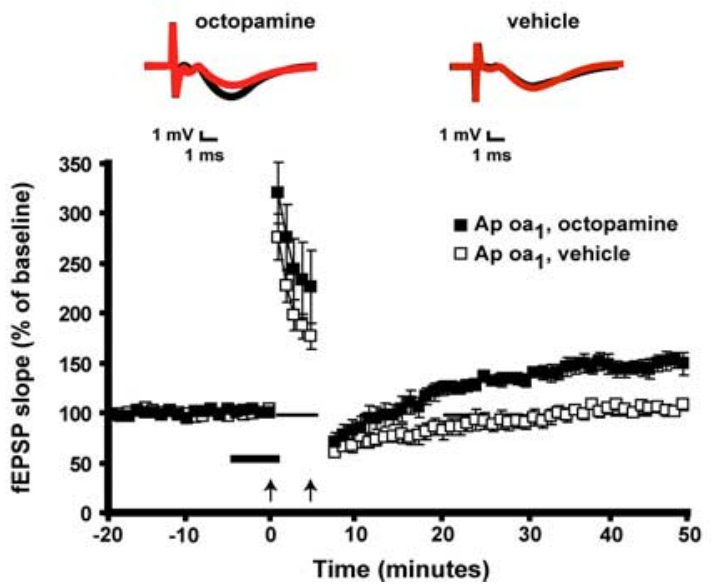

Figure 3. Hippocampal one-train LTP is potentiated and lengthened in $\mathrm{Ap}_{\mathrm{O}} \mathrm{a}_{1}$ mice after octopamine application. A, 0ctopamine (100 $\mu \mathrm{M})$ has no effect on test fEPSPs generated at the CA3-CA1 synapses of Ap $0 a_{1}$ transgenic mice ( $n=6$ from 6 mice; Ap $0 a_{1}$, octopamine, no tetanus; gray squares). However, when LTP is induced by a single tetanus of $100 \mathrm{~Hz}$ for $1 \mathrm{~s}$ after 4 min of $100 \mu \mathrm{m}$ octopamine bath application, the resultant LTP is both larger and longer lasting in hippocampal slices from Ap oa ${ }_{1}$ transgenic mice ( $n=8$ slices from 8 mice; Ap oa ${ }_{1}$, octopamine; black squares) than in hippocampal slices from Ap oa, transgenic mice exposed to vehicle ( $n=9$ slices from 9 mice; Ap oa ${ }_{1}$, vehicle; white squares) and in hippocampal slices from wild-type mice exposed to octopamine ( $n=9$ slices from 9 mice; WT, octopamine; black circles) or vehicle ( $n=9$ slices from 9 mice; WT, vehicle; white circles). Insets, Superimposed sample

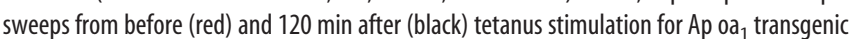

ing a single $1 \mathrm{~s}, 100 \mathrm{~Hz}$ train of electrical stimuli observed in transgenic mice overexpressing a constitutively active form of CREB shared properties with late LTP (L-LTP) triggered by four trains of stimulation, including resistance to depotentiation (Barco et al., 2002, 2005). We therefore performed depotentiation experiments to investigate whether the facilitated E-LTP elicited after brief application of octopamine in the Ap oa trans- $_{1}$ genic mice also confers this resistance to depotentiation to potentiated synapses. We used a single $100 \mathrm{~Hz}$ train stimulation to

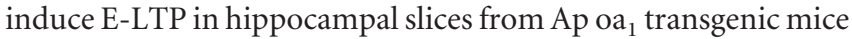
with bath application of either vehicle or octopamine $4 \mathrm{~min}$ before the tetanus, followed by a low-frequency stimulus of $5 \mathrm{~Hz}$ for 3 min (Zhuo et al., 1999) to produce depotentiation (Fig. 3C). This low-frequency stimulus 5 min after the tetanus successfully depotentiated the previously potentiated synapses in Ap oa transgenic mice exposed to vehicle $(107.9 \pm 5 \%$ of baseline at 50 min after stimulus), but failed to depotentiate the synapses in Ap $\mathrm{oa}_{1}$ transgenic mice exposed to octopamine (149.1 $\pm 10 \%$ of baseline at $50 \mathrm{~min}$ after stimulus) (one-way repeated-measures ANOVA, $F_{(1,10)}=29.889 ; p=0.00027$; post hoc Student-Newman-Keuls, $p=0.000429)$. These results show that Ap oa ${ }_{1}$ activation by octopamine treatment endows E-LTP with the resistance to depotentiation that is characteristic of L-LTP.

\section{Inducible enhancement of memory storage and retrieval in} Ap oa transgenic mice $_{1}$

Prompted by the biochemical and physiological effects observed in response to the conditional activation of the $\mathrm{Ap} \mathrm{oa}_{1}$ receptor in the hippocampus of Ap oa ${ }_{1}$ mice, we next examined the effects of acute increases of neuronal cAMP signaling on memory for contextual fear conditioning, a hippocampus-dependent task. Because robust learning can be triggered with a single training trial, contextual fear conditioning is an ideal task for examining the molecular mechanisms underlying the distinct temporal phases of memory. In this form of aversive learning, mice learn to fear an environment because of its temporal association with a footshock. When reexposed to the same context, conditioned mice show a variety of conditional fear responses, including freezing behavior (Fanselow and Poulos, 2005). We first examined performance of Ap oa ${ }_{1}$ transgenic mice and wild-type littermates in this task in the absence of octopamine. Ap $\mathrm{oa}_{1}$ transgenic and wild-type mice showed similar freezing before and after the shock on training day (Fig. 4A) (preshock: WT, $2.0 \pm 1.4 \%$; Ap oa ${ }_{1}$, $4.1 \pm 1.8 \% ; p=0.36$, NS; postshock: WT, $10.4 \pm 4.6 \%$; Ap oa $_{1}$, $12.5 \pm 4.4 \%$; Student's $t$ test, $p=0.73$, NS), as well as during the test for contextual long-term memory performed $24 \mathrm{~h}$ later (Fig. $4 A$ ) (24 h test: WT, $32.7 \pm 6.1 \%$; Ap oa $_{1}, 37.2 \pm 5.4 \%$; Student's $t$ test, $p=0.55$, NS). These data show that in the absence of octopamine, expression of the Ap oa ${ }_{1}$ per se does not interfere with learning or memory of contextual fear conditioning.

Previous studies performing pharmacological inhibition of

\section{$\leftarrow$}

mice and wild-type mice. The arrow indicates when the potentiation stimulus was delivered. $\boldsymbol{B}$, At 60 and 120 min after tetanic stimulation, slices from $A p$ oa $a_{1}$ transgenic mice incubated with octopamine ( $\left.A p 0 a_{1}, O A\right)$ exhibit significantly higher potentiation than those incubated with vehicle $\left(A p 0 a_{1}, V\right)$ and slices from wild-type mice incubated with octopamine (WT, OA) or vehicle (WT, V). C, Five minutes after inducing LTP with a single $100 \mathrm{~Hz}$ stimulus, $5 \mathrm{~Hz}$ stimulation for 3 min depotentiated the previously evoked LTP in the Ap oa ${ }_{1}$ transgenic mice incubated with vehicle ( 6 slices from 6 mice; white squares), but failed to depotentiate the LTP in the Ap $0 a_{1}$ transgenic mice incubated with octopamine ( 6 slices from 6 mice; black squares) for 4 min right before tetanus stimulus. Arrows indicate when the potentiation and depotentiation stimuli were delivered. Values are mean \pm SEM. ${ }^{* * *} p<0.005$. 
A

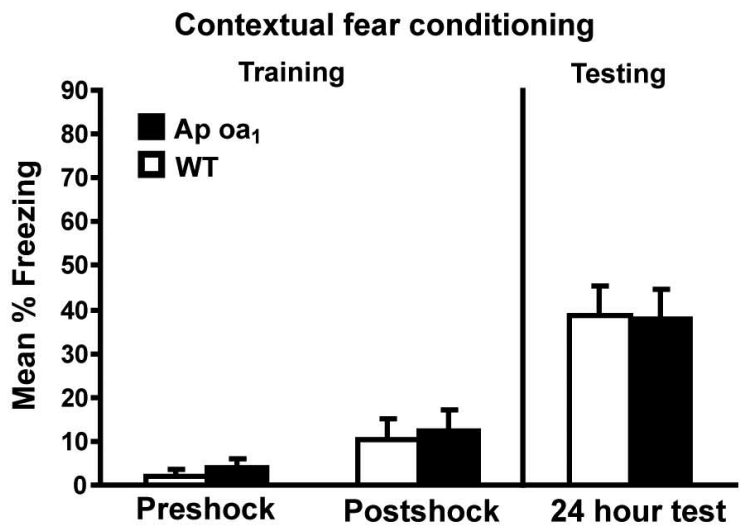

B

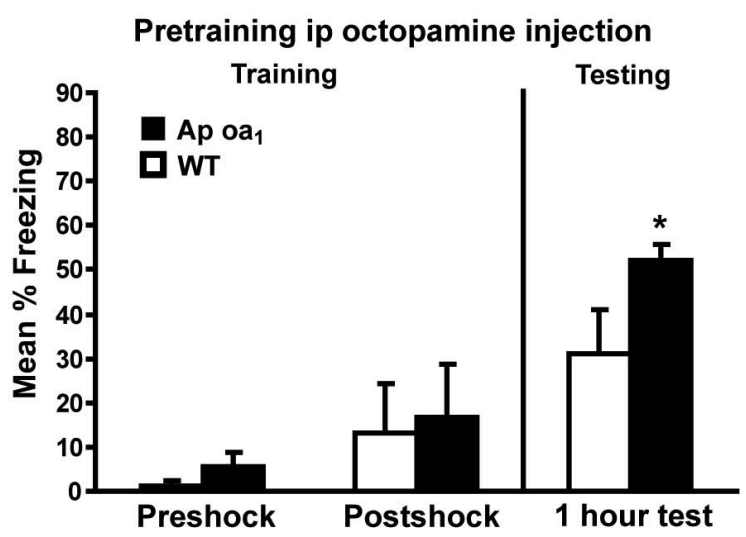

C

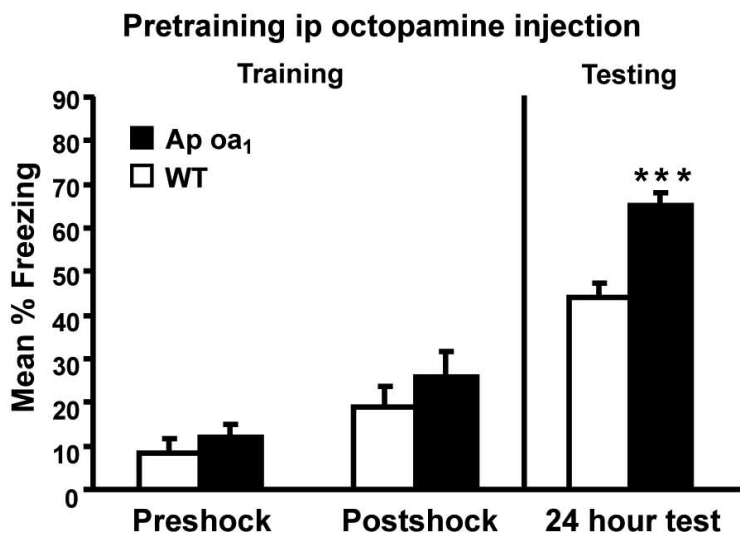

Figure 4. Ap $0 \mathrm{a}_{1}$ transgenic mice exhibit enhanced short- and long-term memory for contextual fear conditioning but normal learning after octopamine injection. $A$, Training and $24 \mathrm{~h}$ long-term memory test during contextual fear conditioning in the absence of octopamine. There is no difference in freezing behavior between $\mathrm{Ap} \mathrm{oa}_{1}$ transgenic mice $(n=8)$ and wildtype littermates $(n=8)$ during training either before (Preshock) or after (Postshock) the shock, or during testing $24 \mathrm{~h}$ later. $\boldsymbol{B}$, Training and $1 \mathrm{~h}$ short-term memory test during contextual fear conditioning in Ap $0 \mathrm{a}_{1}$ transgenic and wild-type littermates when octopamine $(1 \mathrm{mg} / \mathrm{kg})$ is injected intraperitoneally $30 \mathrm{~min}$ before training. Ap oa, transgenic mice $(n=6)$ and wild-type littermates $(n=6)$ show the same levels of freezing before and after the shock during training. However, Ap oa ${ }_{1}$ transgenic mice exhibit significantly higher levels of freezing when reexposed to the fear-conditioned context $1 \mathrm{~h}$ after training. $C$, Training and $24 \mathrm{~h}$ long-term memory test during contextual fear conditioning in a different set of $A p ~ 0 \mathrm{a}_{1}$ transgenic mice and wild-type littermates injected intraperitoneally with octopamine $30 \mathrm{~min}$ before training. No differences in freezing behavior are observed between $\mathrm{Ap}_{0} \mathrm{a}_{1}$ transgenic mice $(n=20)$ and wild-type littermates $(n=19)$ before and after the shock during training. In contrast, Ap oa 1 transgenic mice show a significant increase in freezing behavior when reexposed to the fear-conditioned context $24 \mathrm{~h}$ after training. Values are mean \pm SEM. ${ }^{*} p<0.05 ;{ }^{* * *} p<0.005$.
cAMP signaling suggested a role for cAMP in establishing shortand long-term memory for context-dependent fear conditioning (Bourtchouladze et al., 1998; Ahi et al., 2004). To examine whether Ap $\mathrm{oa}_{1}$ activation had an effect on initial acquisition and/or on short- and long-term memory for contextual fear conditioning, Ap oa ${ }_{1}$ transgenic mice and wild-type littermates were injected intraperitoneally with $1 \mathrm{mg} / \mathrm{kg}$ octopamine $30 \mathrm{~min}$ before fear conditioning. We found that immediate freezing responses were similar in Ap oa ${ }_{1}$ transgenic mice and wild-type controls after the shock on training day [postshock: WT, $13.3 \pm$ $10.8 \%$; $\mathrm{Ap} \mathrm{oa}_{1}, 16.6 \pm 11.8 \%$; Student's $t$ test, $p=0.82$, NS (Fig. $4 B)$; postshock: WT, $18.9 \pm 5.0 \%$; Ap oa $1,26.0 \pm 5.7 \%$; Student's $t$ test, $p=0.35$, NS (Fig. 4C)], indicating that activation of the Ap $\mathrm{oa}_{1}$ does not affect the acquisition of fear conditioning and the expression of freezing behavior. In contrast, Ap oa ${ }_{1}$ transgenic mice froze significantly more than control mice when tested for short-term memory $1 \mathrm{~h}$ after training (Fig. $4 B$ ) (WT, $31.0 \pm$ $10.1 \%$; $\mathrm{Ap} \mathrm{oa}_{1}, 52.3 \pm 3.6 \%$; Student's $t$ test, $\left.p=0.05\right)$, as well as when tested for long-term memory $24 \mathrm{~h}$ after training (Fig. $4 \mathrm{C}$ ) (WT, $44.4 \pm 3.1 \%$; Ap oa $1,65.4 \pm 3.0 \%$; Student's $t$ test, $p=$ 0.000018 ), suggesting that activation of the receptor enhances both short- and long-term memory for contextual fear conditioning in the transgenic mice. Moreover, freezing levels of wildtype mice receiving octopamine were similar to those showed by wild-type mice not injected with octopamine, during both the training and the testing sessions (Fig. $4 A-C$ ), indicating that intraperitoneal administration of octopamine per se does not affect aspects of performance such as perception of the environment, nociception, motor activity, or freezing behavior.

The apparent memory enhancement that we observed in Ap $\mathrm{oa}_{1}$ mice after systemic octopamine administration may be attributable to the effects of Ap $\mathrm{oa}_{1}$ activation on acquisition, consolidation, and/or retrieval. Previous studies showed that cAMP signaling critically modulates memory consolidation (for review, see Kandel, 2001), and during consolidation of long-term memory for fear conditioning, two periods have been found to be sensitive to pharmacological inhibition of the cAMP pathways, one around the time of training and the other 3-6 h after training (Bernabeu et al., 1997; Bourtchouladze et al., 1998). In contrast, pharmacological boosting of cAMP levels during the late but not during the early period of consolidation leads to enhanced memory (Bernabeu et al., 1997). We therefore examined the effects of activating the Ap oa ${ }_{1}$ receptor during the early and late phases of fear memory consolidation. It is known that trace amines such as octopamine in the CNS readily cross cell membranes and have a short half-life (30 s), and that their action is terminated after diffusion from the synaptic cleft into either postsynaptic or presynaptic structures, where enzymatic degradation by monoamine oxidase occurs (Durden and Philips, 1980; Paterson et al., 1990). Based on this evidence, we hypothesized that intracerebroventricular infusion of octopamine would activate the Ap oa in a transient manner as a result of the rapid inactivation of octopamine, thereby allowing us to tease apart the effects of Ap oa ${ }_{1}$ activation on the early versus the late stages of memory consolidation, as described by the pharmacological approach (Bernabeu et al., 1997). Thus, we performed intracerebroventricular infusions of octopamine immediately after and $3 \mathrm{~h}$ after training (Fig. 5B). In a $24 \mathrm{~h}$ test, we found that although wild-type and $\mathrm{Ap} \mathrm{oa}$ mice showed similar freezing when injected immediately after training (WT/vehicle, $33.6 \pm 6.0 \%$; WT/octopamine, $30.5 \pm 4.7 \%$; Ap

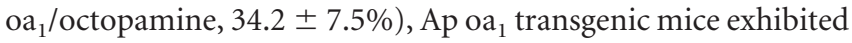
significantly higher freezing when receiving octopamine $3 \mathrm{~h}$ after training than wild-type mice infused with octopamine (Fig. 5B) 

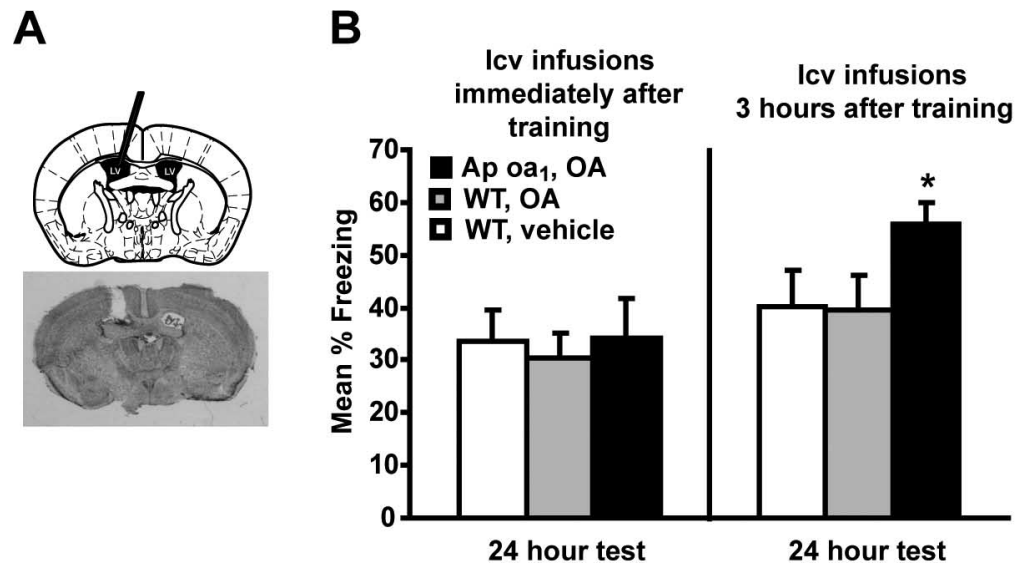

C

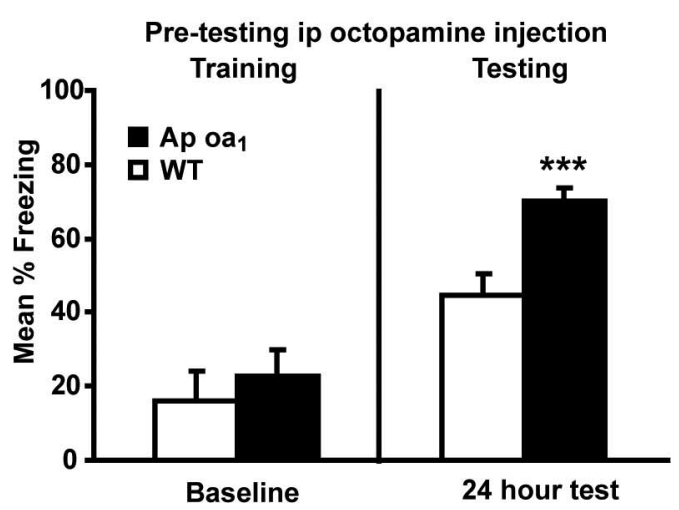

Figure 5. Ap $0 \mathrm{a}_{1}$ transgenic mice exhibit enhanced memory consolidation and retrieval for contextual fear conditioning after octopamine injection. $A$, Top, Schematic depicting location of cannula chronically implanted in the lateral ventricle (LV). Bottom, A representative Nissl-stained coronal brain section of a mouse to verify cannula placement. $B$, Freezing behavior during a $24 \mathrm{~h}$ long-term memory test in wild-type mice injected with vehicle (WT, vehicle) or with $100 \mu \mathrm{g}$ octopamine (WT, OA) intracerebroventricularly and in Ap oa ${ }_{1}$ transgenic mice injected with $100 \mu \mathrm{g}$ octopamine intracerebroventricularly (Ap oa $1,0 \mathrm{~A})$ immediately or $3 \mathrm{~h}$ after training. Wild-type mice injected with vehicle $(n=6)$ or octopamine $(n=6)$ and Ap oa transgenic mice injected with octopamine $(n=6)$ immediately after training show the same levels of freezing to the fear-conditioned context when reexposed $24 \mathrm{~h}$ after training. However, Ap oa ${ }_{1}$ transgenic mice injected with octopamine $(n=16) 3 \mathrm{~h}$ after training exhibit significantly increased freezing behavior compared with wild-type mice injected with vehicle $(n=13)$ and with wild-type mice injected with

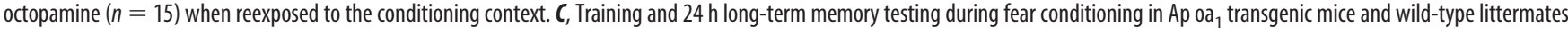
receiving an intraperitoneal injection of octopamine $(1 \mathrm{mg} / \mathrm{kg}) 30 \mathrm{~min}$ before the retrieval session. Ap oa 1 transgenic mice and WT mice show similar levels of freezing during the training session (Baseline). However, Ap oa transgenic mice $(n=8)$ exhibit significantly increased freezing behavior compared with wild-type mice $(n=6)$ during the contextual fear memory test $24 \mathrm{~h}$ after training. Values are mean \pm SEM. ${ }^{*} p<0.05 ;{ }^{* * *} p<0.005$.

(WT/octopamine, $39.4 \pm 6.7 \%$; Ap oa $/$ octopamine, $55.7 \pm$ $4.3 \%$; Student's $t$ test, $p=0.04$ ) or vehicle (WT/vehicle, $40.1 \pm$

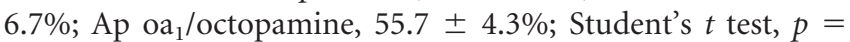
0.04). These data show that activation of the $A p \mathrm{oa}_{1}$ at a late but not at an early stage during consolidation enhances storage of fear memory, and strongly suggest that boosting cAMP signaling pathways within neurons specifically during a late consolidation phase improves memory storage. These results do not, however, rule out a positive modulatory effect of enhanced cAMP signaling on retrieval that indeed was suggested by previous pharmacological studies (Barros et al., 2001; Murchison et al., 2004). To assess the effects of Ap oa activation on retrieval of fear memory, Ap $\mathrm{oa}_{1}$ transgenic and wild-type mice were subjected to contextual fear conditioning, and 30 min before the test session that occurred $24 \mathrm{~h}$ after training, mice were injected intraperitoneally with octopamine. Ap oa ${ }_{1}$ transgenic mice exhibited a significant increase in freezing to the context during the test session (Fig. $5 \mathrm{C}$ ) (WT, $44.4 \pm 6.1 \%$; Ap oa, $70.1 \pm 3.5 \%$; Student's $t$ test, $p=$ 0.002 ), indicating that Ap oa ${ }_{1}$ activation enhanced retrieval for contextual fear memory.

Novel object-recognition tasks rely on the natural exploratory activity of rodents toward novel objects, and they provide a nonaversive single-trial learning paradigm (for review, see Dere et al., 2007). Previous studies suggested that the cAMP pathway and CREB are required for long-term recognition memory but not for acquisition (Bozon et al., 2003; Pineda et al., 2004; Wang et al., 2004). In addition, memory (but not acquisition) of object recognition was enhanced by pharmacological (Bourtchouladze et al., 2003; Rutten et al., 2007) and constitutive genetic (Wang et al., 2004) increases in cAMP signaling. This evidence led us to examine Ap oa ${ }_{1}$ transgenic mice in an object-recognition task. Ap $\mathrm{oa}_{1}$ transgenic mice $(n=6)$ and wild-type littermates $(n=6)$ injected intraperitoneally with $1 \mathrm{mg} / \mathrm{kg}$ octopamine $30 \mathrm{~min}$ before training spent similar amount of time exploring the two objects (WT, $26.2 \pm 9.5 \%$; Ap oa $_{1}, 29.8 \pm 12.8 \%$ ), indicating that Ap $\mathrm{oa}_{1}$ activation did not alter attention, motivation, and visual perception during training. However, in a $24 \mathrm{~h}$ retention test, Ap $\mathrm{oa}_{1}$ transgenic mice exhibited a significantly increased preference for the novel object (WT, $66.9 \pm 1.5 \%$; Ap oa, $72.8 \pm 1.0 \%$; Student's $t$ test, $p=0.01)$. These results show that acute Ap $\mathrm{oa}_{1}$-mediated increases in cAMP may also improve memory for object recognition.

\section{Discussion}

We have described here a novel genetic approach for spatially and temporally regulated, inducible elevation of cAMP signaling in mice based on the heterologous transgenic expression and conditional activation of a $\mathrm{G}_{\mathrm{s}}$-coupled receptor, the Aplysia octopamine receptor. Using this novel genetic system, we have shown that the neuronal cAMP signaling pathway is an ideal target for memory enhancement, and provide the first genetic evidence that increasing cAMP signaling selectively improves consolidation and retrieval of memory. The 50\% increase in cAMP levels in our experiments was approximately one-fourth of the increase reported in response to bath application of the adenylyl cyclase activator forskolin, and one-half of that observed in response to the type IV phosphodiesterase inhibitor rolipram (Barad et al., 1998 ), or the $\beta$-adrenergic receptor agonist isoproterenol (Chetkovich and Sweatt, 1993). However, our results reflect neuronspecific increases in cAMP, and cannot be directly compared with those obtained with pharmacological inducers of cAMP elevation that may cause cAMP increases in other cell types. Our finding that cAMP levels in transgenic hippocampal slices significantly increased after $5 \mathrm{~min}$ of octopamine application but declined after 15 min indicates a rapid and transient elevation of cAMP after receptor activation. These observations are consistent with fluorescent resonance energy transfer studies on the spatiotemporal dynamics of CAMP in neurons that demonstrated the rapidity and short duration of cAMP signals after application of various neuromodulators (Bacskai et al., 1993; Hempel et al., 1996). Unlike bath application of drugs like forskolin and expression of conventional transgenes affecting cAMP, our approach thus produces a biological effect that more closely resembles the dynamics of actual, endogenous cAMP signaling. 
We also show that hippocampal LTP is selectively enhanced in Ap oa ${ }_{1}$ transgenic mice when induced in the presence of octopamine, suggesting that cAMP increases linked to Ap oa ${ }_{1}$ receptor activation contribute to enhanced LTP by amplifying a cAMP transient reported to occur after tetanic stimulation in slices (Chetkovich et al., 1991; Chetkovich and Sweatt, 1993; Frey et al., 1993). Previous studies also suggested a positive modulatory effect of cAMP elevation in hippocampus synaptic plasticity (Barad et al., 1998; Pittenger et al., 2002; Wang et al., 2004; Gelinas and Nguyen, 2005; Wood et al., 2005). Because of the inducibility and molecular specificity of our system, our results extend these data by providing genetic evidence that transient neuronal cAMP signals positively modulate synaptic plasticity.

We have used this novel conditional genetic system to assess the effects of acute increases of neuronal cAMP signaling during different stages of memory. It has been previously reported that shortterm memory may be dependent on cAMP signaling (Ahi et al., 2004) and that it may be enhanced after pharmacological immediate posttraining increases of hippocampal cAMP (Vianna et al., 2000). Our results extend the above-mentioned findings, showing that elevation of cAMP levels in forebrain neurons around the time of training leads to short-term memory enhancements (Fig. 4B). Previous work suggested that memory consolidation is critically modulated by cAMP signaling pathways (Bourtchouladze et al., 1998; Wong et al., 1999) and that pharmacologically induced increases of hippocampal cAMP may improve long-term memory (Bernabeu et al., 1997). Our results further such observations, showing that elevation of forebrain neuronal cAMP at a late but not at an early posttraining phase of memory consolidation is sufficient to enhance memory for contextual fear conditioning (Fig. 5B). These results raise the intriguing question of how an acute increase in cAMP levels late after training may improve memory consolidation. There is evidence that dopaminergic modulatory influences in the hippocampus (Bernabeu et al., 1997; White and Salinas, 2003) and in the amygdala regulate the consolidation of memory (for review, see McGaugh, 2004). Given that $D_{1} / D_{5}$ dopamine receptors are positively coupled to adenylyl cyclase, it is possible that elevation of cAMP levels after Ap oa activation at the time that the adenylyl cyclase-coupled $D_{1} / D_{5}$ receptors are activated during memory consolidation leads to amplification of the modulatory $\mathrm{D}_{1} / \mathrm{D}_{5}$-mediated cAMP signal. One consequence of transient elevation of cAMP levels might be a lowering of the threshold for late-phase LTP induction and memory formation by the alteration of gene expression mediated by CREB, thought to be required for some forms of synaptic plasticity and memory formation (Bourtchuladze et al., 1994; Kida et al., 2002; Pittenger et al., 2002). Future studies looking at transcriptional patterns of genes containing CRE sequences in their promoter regions $3 \mathrm{~h}$ after training in $\mathrm{Ap} \mathrm{oa}_{1}$ transgenic mice and wild-type controls will help to identify cAMP-regulated genes that may mediate this memory enhancement.

The most remarkable finding of the present study is that memory for contextual fear conditioning can be enhanced by acute increases of cAMP signaling selectively in forebrain neurons during retrieval. Previous studies reported that memory retrieval of inhibitory avoidance is enhanced after pharmacological activation of cAMPpositively coupled dopamine $\mathrm{D}_{1}$ receptors in cortical structures and cAMP-positively coupled $\beta$-noradrenergic receptors in the amygdala (Barros et al., 2001). Moreover, $\beta_{1}$-adrenergic signaling in the hippocampus is critical for retrieval of contextual fear memory (Murchison et al., 2004). Based on these studies, one likely explanation for our results is that boosting cAMP levels by activation of Ap $\mathrm{oa}_{1}$ during retrieval leads to amplification of modulatory signals mediated by various receptors positively coupled to adenylyl cyclase, but the downstream targets of this signal remain unclear. Future work examining the effects of Ap oa ${ }_{1}$ activation on additional behavioral tasks will help to elucidate whether increasing cAMP signaling may also facilitate other types of memory, such as spatial memories.

Previous genetic approaches that increased cAMP signaling to test its potential as a target for memory enhancement showed that constitutive upregulation of this pathway has almost no effect (Wang et al., 2004), and in some reports actually has deleterious effects on memory (Abel et al., 1997; Pineda et al., 2004; Bourtchouladze et al., 2006). In contrast, by using our novel conditional system, we demonstrate that acute upregulation of cAMP levels selectively in forebrain neurons can lead to enhanced memory. The exceptional temporal resolution and cell specificity of this genetic system allow us to identify late consolidation and retrieval as the memory phases at which enhancing cAMP signaling in neurons has positive effects on memory, which may have clinical implications when targeting this pathway to treat memory-related disorders.

In summary, the conditional and rapid activation demonstrated by our biochemical, electrophysiological, and behavioral results, together with the evidence that the Aplysia octopamine receptor is not readily activated by endogenous compounds (Chang et al., 2000), and that its natural ligand octopamine lacks specific receptors in vertebrates (Berry, 2004), indicate that this heterologous conditional genetic system is an ideal tool to study cAMP-mediated processes in mammalian systems. In combination with discrete tissue or cell type expression by the use of specific promoters, this conditional system is uniquely suited to probe the acute role of receptor-mediated cAMP signaling in normal cell function.

\section{References}

Abel T, Nguyen PV, Barad M, Deuel TA, Kandel ER, Bourtchouladze R (1997) Genetic demonstration of a role for PKA in the late phase of LTP and in hippocampus-based long-term memory. Cell 88:615-626.

Ahi J, Radulovic J, Spiess J (2004) The role of hippocampal signaling cascades in consolidation of fear memory. Behav Brain Res 149:17-31.

Allen NJ, Barres BA (2005) Signaling between glia and neurons: focus on synaptic plasticity. Curr Opin Neurobiol 15:542-548.

Bacskai BJ, Hochner B, Mahaut-Smith M, Adams SR, Kaang BK, Kandel ER, Tsien RY (1993) Spatially resolved dynamics of cAMP and protein kinase A subunits in Aplysia sensory neurons. Science 260:222-226.

Barad M, Bourtchouladze R, Winder DG, Golan H, Kandel E (1998) Rolipram, a type IV-specific phosphodiesterase inhibitor, facilitates the establishment of long-lasting long-term potentiation and improves memory. Proc Natl Acad Sci USA 95:15020-15025.

Barco A, Alarcon JM, Kandel ER (2002) Expression of constitutively active CREB protein facilitates the late phase of long-term potentiation by enhancing synaptic capture. Cell 108:689-703.

Barco A, Patterson S, Alarcon JM, Gromova P, Mata-Roig M, Morozov A, Kandel ER (2005) Gene expression profiling of facilitated L-LTP in VP16-CREB mice reveals that BDNF is critical for the maintenance of LTP and its synaptic capture. Neuron 48:123-137.

Barros DM, Mello e Souza T, De David T, Choi H, Aguzzoli A, Madche C, Ardenghi P, Medina JH, Izquierdo I (2001) Simultaneous modulation of retrieval by dopaminergic $\mathrm{D}(1)$, beta-noradrenergic, serotonergic-1A and cholinergic muscarinic receptors in cortical structures of the rat. Behav Brain Res 124:1-7.

Bernabeu R, Bevilaqua L, Ardenghi P, Bromberg E, Schmitz P, Bianchin M, Izquierdo I, Medina JH (1997) Involvement of hippocampal cAMP/ cAMP-dependent protein kinase signaling pathways in a late memory consolidation phase of aversively motivated learning in rats. Proc Natl Acad Sci USA 94:7041-7046.

Berry MD (2004) Mammalian central nervous system trace amines. Pharmacologic amphetamines, physiologic neuromodulators. J Neurochem 90:257-271.

Bourtchouladze R, Abel T, Berman N, Gordon R, Lapidus K, Kandel ER (1998) Different training procedures recruit either one or two critical 
periods for contextual memory consolidation, each of which requires protein synthesis and PKA. Learn Mem 5:365-374.

Bourtchouladze R, Lidge R, Catapano R, Stanley J, Gossweiler S, Romashko D, Scott R, Tully T (2003) A mouse model of Rubinstein-Taybi syndrome: defective long-term memory is ameliorated by inhibitors of phosphodiesterase 4. Proc Natl Acad Sci USA 100:10518-10522.

Bourtchouladze R, Patterson SL, Kelly MP, Kreibich A, Kandel ER, Abel T (2006) Chronically increased Gsalpha signaling disrupts associative and spatial learning. Learn Mem 13:745-752.

Bourtchuladze R, Frenguelli B, Blendy J, Cioffi D, Schutz G, Silva AJ (1994) Deficient long-term memory in mice with a targeted mutation of the cAMP-responsive element-binding protein. Cell 79:59-68.

Bozon B, Kelly A, Josselyn SA, Silva AJ, Davis S, Laroche S (2003) MAPK, CREB and zif268 are all required for the consolidation of recognition memory. Philos Trans R Soc Lond B Biol Sci 358:805-814.

Bradford MM (1976) A rapid and sensitive method for the quantitation of microgram quantities of protein utilizing the principle of protein-dye binding. Anal Biochem 72:248-254.

Chang DJ, Li XC, Lee YS, Kim HK, Kim US, Cho NJ, Lo X, Weiss KR, Kandel ER, Kaang BK (2000) Activation of a heterologously expressed octopamine receptor coupled only to adenylyl cyclase produces all the features of presynaptic facilitation in Aplysia sensory neurons. Proc Natl Acad Sci USA 97:1829-1834.

Chetkovich DM, Sweatt JD (1993) nMDA receptor activation increases cyclic AMP in area CA1 of the hippocampus via calcium/calmodulin stimulation of adenylyl cyclase. J Neurochem 61:1933-1942.

Chetkovich DM, Gray R, Johnston D, Sweatt JD (1991) N-methyl-Daspartate receptor activation increases cAMP levels and voltage-gated $\mathrm{Ca} 2+$ channel activity in area CA1 of hippocampus. Proc Natl Acad Sci USA 88:6467-6471.

Dere E, Huston JP, De Souza Silva MA (2007) The pharmacology, neuroanatomy and neurogenetics of one-trial object recognition in rodents. Neurosci Biobehav Rev 31:673-704.

Dudai Y, Jan YN, Byers D, Quinn WG, Benzer S (1976) dunce, a mutant of Drosophila deficient in learning. Proc Natl Acad Sci USA 73:1684-1688.

Duffy SN, Craddock KJ, Abel T, Nguyen PV (2001) Environmental enrichment modifies the PKA-dependence of hippocampal LTP and improves hippocampus-dependent memory. Learn Mem 8:26-34.

Durden DA, Philips SR (1980) Kinetic measurements of the turnover rates of phenylethylamine and tryptamine in vivo in the rat brain. J Neurochem 34:1725-1732.

Fanselow MS (1980) Conditioned and unconditional components of postshock freezing. Pavlov J Biol Sci 15:177-182.

Fanselow MS, Poulos AM (2005) The neuroscience of mammalian associative learning. Annu Rev Psychol 56:207-234.

Färber K, Pannasch U, Kettenmann H (2005) Dopamine and noradrenaline control distinct functions in rodent microglial cells. Mol Cell Neurosci 29:128-138.

Farooqui T (2007) Octopamine-mediated neuromodulation of insect senses. Neurochem Res 32:1511-1529.

Franklin K, Paxinos G (1997) The mouse brain in stereotaxic coordinates. San Diego: Academic.

Frey U, Huang YY, Kandel ER (1993) Effects of cAMP simulate a late stage of LTP in hippocampal CA1 neurons. Science 260:1661-1664.

Gelinas JN, Nguyen PV (2005) $\beta$-Adrenergic receptor activation facilitates induction of a protein synthesis-dependent late phase of long-term potentiation. J Neurosci 25:3294-3303.

Hempel CM, Vincent P, Adams SR, Tsien RY, Selverston AI (1996) Spatiotemporal dynamics of cyclic AMP signals in an intact neural circuit. Nature 384:166-169.

Josselyn SA, Nguyen PV (2005) CREB, synapses and memory disorders: past progress and future challenges. Curr Drug Targets CNS Neurol Disord 4:481-497.

Kandel ER (2001) The molecular biology of memory storage: a dialog between genes and synapses. Biosci Rep 21:565-611.

Kandel ER (2004) The molecular biology of memory storage: a dialog between genes and synapses. Biosci Rep 24:475-522.

Kida S, Josselyn SA, de Ortiz SP, Kogan JH, Chevere I, Masushige S, Silva AJ (2002) CREB required for the stability of new and reactivated fear memories. Nat Neurosci 5:348-355.

Krzan M, Wu VW, Schwartz JP (2001) Serotonin regulation of nerve growth factor synthesis in neonatal and adult astrocytes: comparison to the betaadrenergic agonist isoproterenol. J Neurosci Res 64:261-267.

Maren S (2005) Synaptic mechanisms of associative memory in the amygdala. Neuron 47:783-786.

Mayford M, Bach ME, Huang YY, Wang L, Hawkins RD, Kandel ER (1996) Control of memory formation through regulated expression of a CaMKII transgene. Science 274:1678-1683.

McGaugh JL (2004) The amygdala modulates the consolidation of memories of emotionally arousing experiences. Annu Rev Neurosci 27:1-28.

Milner TA, Shah P, Pierce JP (2000) Beta-adrenergic receptors primarily are located on the dendrites of granule cells and interneurons but also are found on astrocytes and a few presynaptic profiles in the rat dentate gyrus. Synapse 36:178-193.

Murchison CF, Zhang XY, Zhang WP, Ouyang M, Lee A, Thomas SA (2004) A distinct role for norepinephrine in memory retrieval. Cell 117:131-143.

Narita M, Miyatake M, Narita M, Shibasaki M, Shindo K, Nakamura A, Kuzumaki N, Nagumo Y, Suzuki T (2006) Direct evidence of astrocytic modulation in the development of rewarding effects induced by drugs of abuse. Neuropsychopharmacology 31:2476-2488.

Pascual O, Casper KB, Kubera C, Zhang J, Revilla-Sanchez R, Sul JY, Takano H, Moss SJ, McCarthy K, Haydon PG (2005) Astrocytic purinergic signaling coordinates synaptic networks. Science 310:113-116.

Paterson IA, Juorio AV, Boulton AA (1990) 2-Phenylethylamine: a modulator of catecholamine transmission in the mammalian central nervous system? J Neurochem 55:1827-1837.

Pineda VV, Athos JI, Wang H, Celver J, Ippolito D, Boulay G, Birnbaumer L, Storm DR (2004) Removal of G(ialpha1) constraints on adenylyl cyclase in the hippocampus enhances LTP and impairs memory formation. Neuron 41:153-163.

Pittenger C, Huang YY, Paletzki RF, Bourtchouladze R, Scanlin H, Vronskaya S, Kandel ER (2002) Reversible inhibition of CREB/ATF transcription factors in region CA1 of the dorsal hippocampus disrupts hippocampusdependent spatial memory. Neuron 34:447-462.

Rutten K, Prickaerts J, Hendrix M, van der Staay FJ, Sik A, Blokland A (2007) Time-dependent involvement of cAMP and cGMP in consolidation of object memory: studies using selective phosphodiesterase type 2, 4 and 5 inhibitors. Eur J Pharmacol 558:107-112.

Skoulakis EM, Grammenoudi S (2006) Dunces and da Vincis: the genetics of learning and memory in Drosophila. Cell Mol Life Sci 63:975-988.

Taylor JR, Birnbaum S, Ubriani R, Arnsten AF (1999) Activation of cAMPdependent protein kinase $\mathrm{A}$ in prefrontal cortex impairs working memory performance. J Neurosci 19:RC23(1-5).

Vianna MR, Izquierdo LA, Barros DM, Ardenghi P, Pereira P, Rodrigues C, Moletta B, Medina JH, Izquierdo I (2000) Differential role of hippocampal cAMP-dependent protein kinase in short- and long-term memory. Neurochem Res 25:621-626.

Wang H, Storm DR (2003) Calmodulin-regulated adenylyl cyclases: crosstalk and plasticity in the central nervous system. Mol Pharmacol 63:463-468.

Wang H, Ferguson GD, Pineda VV, Cundiff PE, Storm DR (2004) Overexpression of type-1 adenylyl cyclase in mouse forebrain enhances recognition memory and LTP. Nat Neurosci 7:635-642.

White NM, Salinas JA (2003) Mnemonic functions of dorsal striatum and hippocampus in aversive conditioning. Behav Brain Res 142:99-107.

Wong ST, Athos J, Figueroa XA, Pineda VV, Schaefer ML, Chavkin CC, Muglia LJ, Storm DR (1999) Calcium-stimulated adenylyl cyclase activity is critical for hippocampus-dependent long-term memory and late phase LTP. Neuron 23:787-798.

Wood MA, Kaplan MP, Park A, Blanchard EJ, Oliveira AM, Lombardi TL, Abel T (2005) Transgenic mice expressing a truncated form of CREBbinding protein (CBP) exhibit deficits in hippocampal synaptic plasticity and memory storage. Learn Mem 12:111-119.

Zhang WP, Ouyang M, Thomas SA (2004) Potency of catecholamines and other L-tyrosine derivatives at the cloned mouse adrenergic receptors. Neuropharmacology 47:438-449.

Zhao MG, Toyoda H, Lee YS, Wu LJ, Ko SW, Zhang XH, Jia Y, Shum F, Xu H, Li BM, Kaang BK, Zhuo M (2005) Roles of NMDA NR2B subtype receptor in prefrontal long-term potentiation and contextual fear memory. Neuron 47:859-872.

Zhuo M, Zhang W, Son H, Mansuy I, Sobel RA, Seidman J, Kandel ER (1999) A selective role of calcineurin $\mathrm{A} \alpha$ in synaptic depotentiation in hippocampus. Proc Natl Acad Sci USA 96:4650-4655. 